\title{
Luxembourg: 2017 Article IV Consultation- Press Release; Staff Report; and Statement by the Executive Director For Luxembourg
}




\section{INTERNATIONAL MONETARY FUND}

\section{LUXEMBOURG}

IMF Country Report No. 17/113

\section{ARTICLE IV CONSULTATION-PRESS RELEASE; STAFF REPORT; AND STATEMENT BY THE EXECUTIVE DIRECTOR FOR LUXEMBOURG}

Under Article IV of the IMF's Articles of Agreement, the IMF holds bilateral discussions with members, usually every year. In the context of the 2017 Article IV consultation with Luxembourg, the following documents have been released and are included in this package:

- A Press Release summarizing the views of the Executive Board as expressed during its May 5, 2017 consideration of the staff report that concluded the Article IV consultation with Luxembourg.

- The Staff Report prepared by a staff team of the IMF for the Executive Board's consideration on May 5, 2017, following discussions that ended on March 7, 2017, with the officials of Luxembourg on economic developments and policies. Based on information available at the time of these discussions, the staff report was completed on April 14, 2017.

- An Informational Annex prepared by the IMF staff.

- A Staff Supplement updating information on recent developments.

- A Statement by the Executive Director of Luxembourg.

The following document has been or will be separately released.

Selected Issues Paper

The IMF's transparency policy allows for the deletion of market-sensitive information and premature disclosure of the authorities' policy intentions in published staff reports and other documents.

Copies of this report are available to the public from
International Monetary Fund • Publication Services
PO Box 92780 - Washington, D.C. 20090
Telephone: (202) 623-7430 • Fax: (202) 623-7201
E-mail: publications@imf.org Web: http://www.imf.org

Price: $\$ 18.00$ per printed copy

\section{International Monetary Fund Washington, D.C.}

(c) 2017 International Monetary Fund

CInternational Monetary Fund. Not for Redistribution 
Press Release No. 17/158

FOR IMMEDIATE RELEASE

May 10, 2017
International Monetary Fund

$70019^{\text {th }}$ Street, NW

Washington, D. C. 20431 USA

\section{IMF Executive Board Concludes 2017 Article IV Consultation with Luxembourg}

On May 5, 2017, the Executive Board of the International Monetary Fund (IMF) concluded the Article IV consultation with Luxembourg. ${ }^{1}$

Benefiting from its major role in intermediating international capital flows, Luxembourg has enjoyed strong growth supported by competitive advantages of fiscal stability, a qualified workforce, and business friendly regulations and oversight. Economic growth reached 4.2 percent in 2016, well above the EU average, and was driven by net exports of financial services. Growth is projected at 3.8 percent this year, with continued strong job creation and a pick-up in inflation.

In 2016, buoyant tax revenues due to higher-than-expected economic activity contributed to a fiscal surplus of 1.6 percent of GDP. In 2017, the tax reform is expected to result in a drop in the fiscal surplus and a broadly balanced budget over the medium-term.

Growth prospects are good but are subject to downside risks, including from a retreat from cross-border integration, policy uncertainty in the U.S. and related to upcoming elections in Europe and Brexit that could result in financial market volatility affecting the financial system. Luxembourg also remains vulnerable to lower-than-expected growth in Europe and challenges to the euro area architecture. The ongoing implementation of the international tax transparency and anti-tax avoidance agenda, which Luxembourg has embraced, could weigh on economic activity and tax revenue, but creation of a level playing field could also accentuate its other competitive advantages.

\footnotetext{
${ }^{1}$ Under Article IV of the IMF's Articles of Agreement, the IMF holds bilateral discussions with members, usually every year. A staff team visits the country, collects economic and financial information, and discusses with officials the country's economic developments and policies. On return to headquarters, the staff prepares a report, which forms the basis for discussion by the Executive Board.
} 


\section{Executive Board Assessment ${ }^{2}$}

Executive Directors praised the authorities for their prudent policies and strong institutions, which have underpinned the country's continued robust macroeconomic performance. Directors considered that growth prospects remain strong, although clouded by downside risks related to a possible global retreat from cross-border integration, international policy uncertainty that could cause market volatility, as well as changing international tax rules. Against this backdrop, continued efforts are needed to further improve the oversight of the financial system, adapt the tax regime to the changing international environment, and implement structural reforms to diversify the economy and further reduce unemployment.

Directors encouraged the authorities to continue to move toward risk-based supervision and to increase resources for entities safeguarding stability of the large and interconnected financial system. Given global risks, they stressed the importance of continuing to strengthen the oversight of investment funds, including on-site and comprehensive inspections, system-wide stress testing, and engagement with foreign regulators where delegated activities are undertaken. Directors advised more active supervision of waivers of the large exposure limit of foreign oriented banks. They welcomed the authorities' commitment to reinforce the oversight of nonbank holding companies that include banks and to improve risk monitoring. Directors recommended continued close monitoring of risks in the real estate market, and to stand ready to adjust policies if necessary. Directors encouraged an increase in the capital of the central bank to bolster its financial buffer.

Directors commended the authorities' ongoing commitment to prudent fiscal policies. They endorsed further widening the corporate tax base and maintaining fiscal buffers, including low public debt over the medium term. Directors welcomed the authorities' proactive engagement to implement the European and global tax transparency and anti-tax avoidance initiatives. They considered that contingency measures should be put in place to address revenue risks that may arise from implementation of this agenda, and from volatile financial flows. Directors also recommended continued reform of the pension system to ensure its long-term viability.

Directors welcomed the authorities' structural reform efforts to expand activity beyond the financial sector to enhance the resilience of the economy. They considered that additional product market reforms, active labor market policies, and education reform are needed to support further diversification of the economy, reduce skills mismatches and inactivity traps, and ease supply side constraints in the real estate market.

\footnotetext{
${ }^{2}$ At the conclusion of the discussion, the Managing Director, as Chairman of the Board, summarizes the views of Executive Directors, and this summary is transmitted to the country's authorities. An explanation of any qualifiers used in summings up can be found here: http://www.imf.org/external/np/sec/misc/qualifiers.htm.
} 


\begin{tabular}{|c|c|c|c|c|c|c|}
\hline \multicolumn{7}{|c|}{ Luxembourg: Selected Economic Indicators, 2012-17 } \\
\hline & \multirow[t]{2}{*}{2012} & \multirow[t]{2}{*}{2013} & \multirow[t]{2}{*}{2014} & \multirow[t]{2}{*}{2015} & 2016 & 2017 \\
\hline & & & & & Est. & Proj. \\
\hline Real economy & \multicolumn{6}{|c|}{ (Change in percent, unless otherwise indicated) } \\
\hline Real GDP & -0.4 & 4.0 & 5.6 & 4.0 & 4.2 & 3.8 \\
\hline Gross investment & 0.9 & -2.4 & 8.3 & 3.4 & -0.8 & 2.6 \\
\hline Unemployment (percent of the labor force) & 6.1 & 6.9 & 7.1 & 6.8 & 6.4 & 5.9 \\
\hline Resident employment (thousands) & 229.6 & 234.2 & 239.6 & 244.6 & 249.9 & 255.8 \\
\hline Total employment (thousands) & 379.1 & 385.5 & 395.9 & 406.3 & 418.5 & 429.1 \\
\hline CPI (harmonized), p.a. & 2.9 & 1.7 & 0.7 & 0.1 & 0.0 & 1.2 \\
\hline Public finances & \multicolumn{6}{|c|}{ (Percent of GDP) } \\
\hline General government revenues & 44.4 & 44.3 & 43.2 & 42.7 & 42.7 & 41.4 \\
\hline General government expenditures & 44.1 & 43.3 & 41.8 & 41.3 & 41.1 & 41.2 \\
\hline General government balance & 0.3 & 1.0 & 1.4 & 1.4 & 1.6 & 0.2 \\
\hline General government gross debt & 21.7 & 23.4 & 22.4 & 21.6 & 20.0 & 20.8 \\
\hline \multicolumn{7}{|l|}{ Balance of payments } \\
\hline Current account balance & 5.9 & 5.6 & 5.0 & 5.1 & 4.7 & 4.6 \\
\hline Balance of trade in goods and services & 29.3 & 29.7 & 32.8 & 33.9 & 32.0 & 30.8 \\
\hline Factor income balance & -22.9 & -24.7 & -28.6 & -30.5 & -28.5 & -27.8 \\
\hline Transfer balance & -0.5 & 0.6 & 0.8 & 1.7 & 1.1 & 1.5 \\
\hline Exchange rates & \multicolumn{6}{|c|}{ Member of the euro area } \\
\hline U.S. dollar per euro & 1.3 & 1.3 & 1.3 & 1.1 & 1.1 & $\ldots$ \\
\hline Nominal effective rate $(2010=100)$ & 98.1 & 100.2 & 100.5 & 97.0 & 98.9 & $\ldots$ \\
\hline \multicolumn{7}{|c|}{ Sources: Data provided by the authorities; IMF, WEO database; and IMF staff estimates. } \\
\hline
\end{tabular}




\title{
INTERNATIONAL MONETARY FUND
}

\section{LUXEMBOURG}

\section{STAFF REPORT FOR THE 2017 ARTICLE IV CONSULTATION}

April 14, 2017

\section{KEY ISSUES}

\begin{abstract}
Growth has been strong, benefiting from Luxembourg's major role in intermediating international capital flows, and prospects are good. However, the outlook remains clouded by risks arising from possible global retreat from cross-border integration and policy uncertainty and divergence which could cause financial market volatility; from the international tax transparency and anti-tax avoidance agenda; as well as from new shocks to the euro area economy. Unemployment, moderately high relative to historical standards, mainly reflects skills mismatches, and new jobs have increasingly been taken up by cross-border commuters.
\end{abstract}

The financial sector is a key driver of GDP growth, and risks need to be monitored closely. The supervisory regime and risk monitoring in the investment funds sector, including system-wide stress testing, should continue be enhanced as it is a central element of the financial system in Luxembourg. More intrusive supervision of waivers of the large exposure limit of foreign oriented banks would also be important. Risks stemming from the real estate market, to which the State is indirectly exposed through stakes in domestic banks, should continue to be closely assessed and the authorities should stand ready to adjust policies if needed.

The government should carry on its prudent fiscal policies. While Luxembourg has fiscal space, the government should maintain strong fiscal buffers and adapt the tax regime to address potential risks from implementation of the international tax transparency and anti-tax avoidance agenda, EC state aid probes, and volatile financial flows.

Structural reforms and diversification are important to sustain high and inclusive growth in the medium term. Product market reforms, active labor market policies, and education reform would support further diversification of the economy, spur private investment and job creation, address skills mismatches, and provide employment incentives within the generous unemployment and social benefits system. 
Approved By Jörg Decressin (EUR) and Mary Goodman (SPR)
Discussions took place in Luxembourg during February 23-March 7, 2017. The team comprised Messrs. E. De Vrijer (head), T. Tressel, W. Gbohoui (all EUR) and Ms. A. Oeking (FIN), and was assisted from headquarters by Mr. D. Mason and Ms. D. Santos (both EUR). Mr. P. Breuer (MCM, FSAP mission chief) and Ms. A. Hubic (OED) joined the discussions.

\section{CONTENTS}

CONTEXT

RECENT DEVELOPMENTS

OUTLOOK AND RISKS

A. Financial Sector

B. Fiscal Policy $\underline{18}$

C. Structural Reforms and Diversification of the Economy $\underline{20}$

STAFF APPRAISAL

\section{BOXES}

1. Macro-Financial Linkages of Luxembourg Institutional Sectors___ 12

2. Risks in The Real Estate Market___ 14

3. The Tax Reform of $2016 \_18$

\section{FIGURES}

1. Economic Activity _ـ 5

2. Labor Market and Inflation _ $\underline{6}$

3. Financial Sector Developments _ $\underline{8}$

4. External Sector Developments _ $\underline{9}$

5. Growth Projections and Domestic Sentiment__ 10

6. Credit and Housing Market Developments __ 15

7. Fiscal Policy Developments __ 19

8. Structural Reforms and the Diversification of the Economy __ $\underline{23}$

\section{TABLES}

1. Selected Economic Indicators, 2014-22 — $\underline{26}$

2. Balance of Payments, 2014-22_ 27

3. General Government Operations, 2014-22__ $\underline{28}$

4. General Government Financial Balance Sheet, 2012-15__ $\underline{29}$ 
5. International Investment Position, 2012-16__ $\underline{30}$

6. Financial Soundness Indicators, 2012-16 __

7. Public Sector Debt Sustainability Analysis (DSA)_Baseline Scenario ___ $\underline{32}$

8. Public DSA—Composition of Public Debt and Alternative Scenarios__ $\underline{33}$

9. Risk Assessment Matrix __ 34

\section{APPENDICES}

I. International Tax Transparency and Anti-Tax Avoidance Initiatives and EC Decisions on Advanced Tax Rulings $\underline{36}$

II. External Sector Assessment___ $\underline{40}$

III. Financial Sector Oversight in Luxembourg __ 42

IV. 2017 FSAP Recommendations ___ $\underline{43}$

V. Implementation of the 2016 Article IV Recommendations ___ 44 


\section{CONTEXT}

\section{Luxembourg's small open economy continues to benefit from its major role in} intermediating global capital flows. Deep-rooted traditions of political stability and fiscal prudence reflected in a triple AAA sovereign rating, a welcoming investment climate, and a skilled labor force have continued to serve the Luxembourg global financial center well. The brand of Luxembourg's investment funds, second in the world after the US with $€ 3.7$ trillion of assets at the end of 2016, is offered in more than 70 countries, and Luxembourg is the third largest reporting country in the world for both inward and outward direct investment stocks. In spite of bouts of market volatility, the country has continued to benefit from the surge in global financial assets induced by quantitative easing (QE) by the world's major central banks, search for yield, and the internationalization of corporate activities. In the year to September 2016, gross cross-border assets of the country increased by $€ 250$ billion to $€ 9.9$ trillion (193 times GDP).

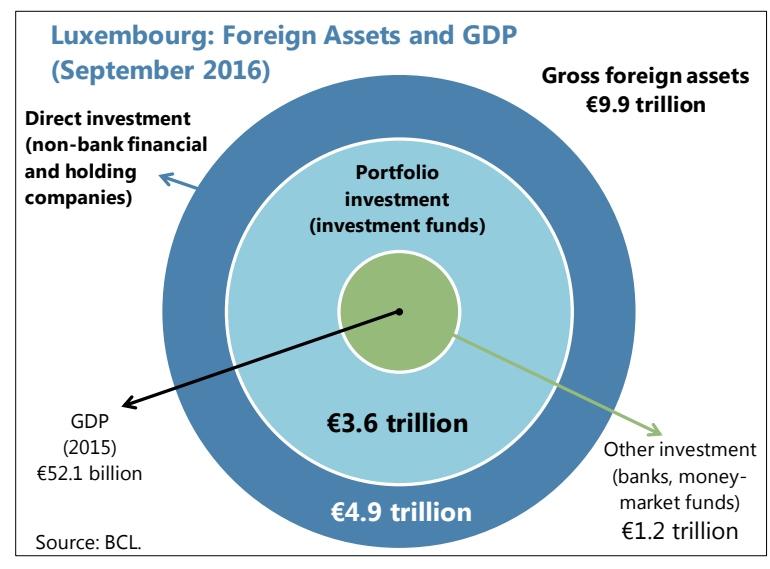

\section{Luxembourg's economic model, in which the State plays a strong role, is facing}

challenges. The State has promoted the financial sector and other industries while ensuring a low and predictable tax environment and business-friendly regulations, including for strategic economic activities. Evolving international tax transparency and anti-tax avoidance rules at the OECD/G20 and EU levels, and European Commission (EC) state aid probes can re-shape and possibly diminish Luxembourg's attractiveness to multinationals and investors. In case of severe external shocks to global financial markets, unraveling multi-billion exposures could disrupt the bank-fund symbiosis model, impacting real GDP and reverberating abroad, and could prompt dislocations far beyond the scope of the national authorities.

3. Luxembourg is planning the future diversification of its economy. Over decades, the Luxembourg business model has emphasized consecutively the steel industry, the Eurobond market, private banking and the investment fund industry. Since the global financial crisis, almost half of new jobs go to cross-border workers mainly from the "Grande Region", who produce an increasing share of value-added while skills mismatches and a generous welfare system have resulted in a higher unemployment rate. The authorities are developing the strategic directions for the next decades.

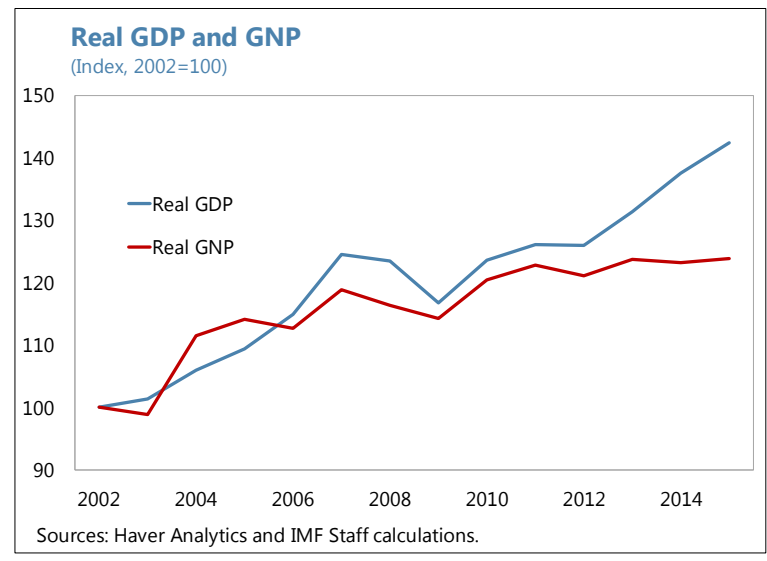




\section{Against this background the 2017 Article IV consultation focuses on the following} areas:

- Financial stability and regulation. Building on the 2017 FSAP, the consultation highlights risks and regulatory challenges related to banks and investment funds, and the macroprudential oversight of the economy, in order to maintain Luxembourg's reputation for sound financial sector supervision.

- International tax transparency and anti-tax avoidance agenda. Luxembourg is facing risks from EC state aid probes and from the EU and the OECD/G20 Base Erosion and Profit Shifting (BEPS) initiatives, which aim to increase international corporate tax transparency and curb tax avoidance, and have implications for the Luxembourg economy that require pro-active consideration of policy options to adapt to the new environment.

- Structural reforms and the diversification of the economy. To counter risks to Luxembourg's economic model, the consultation considers reform options to diversify the economy and reduce skill mismatches, in order to sustain high, inclusive growth.

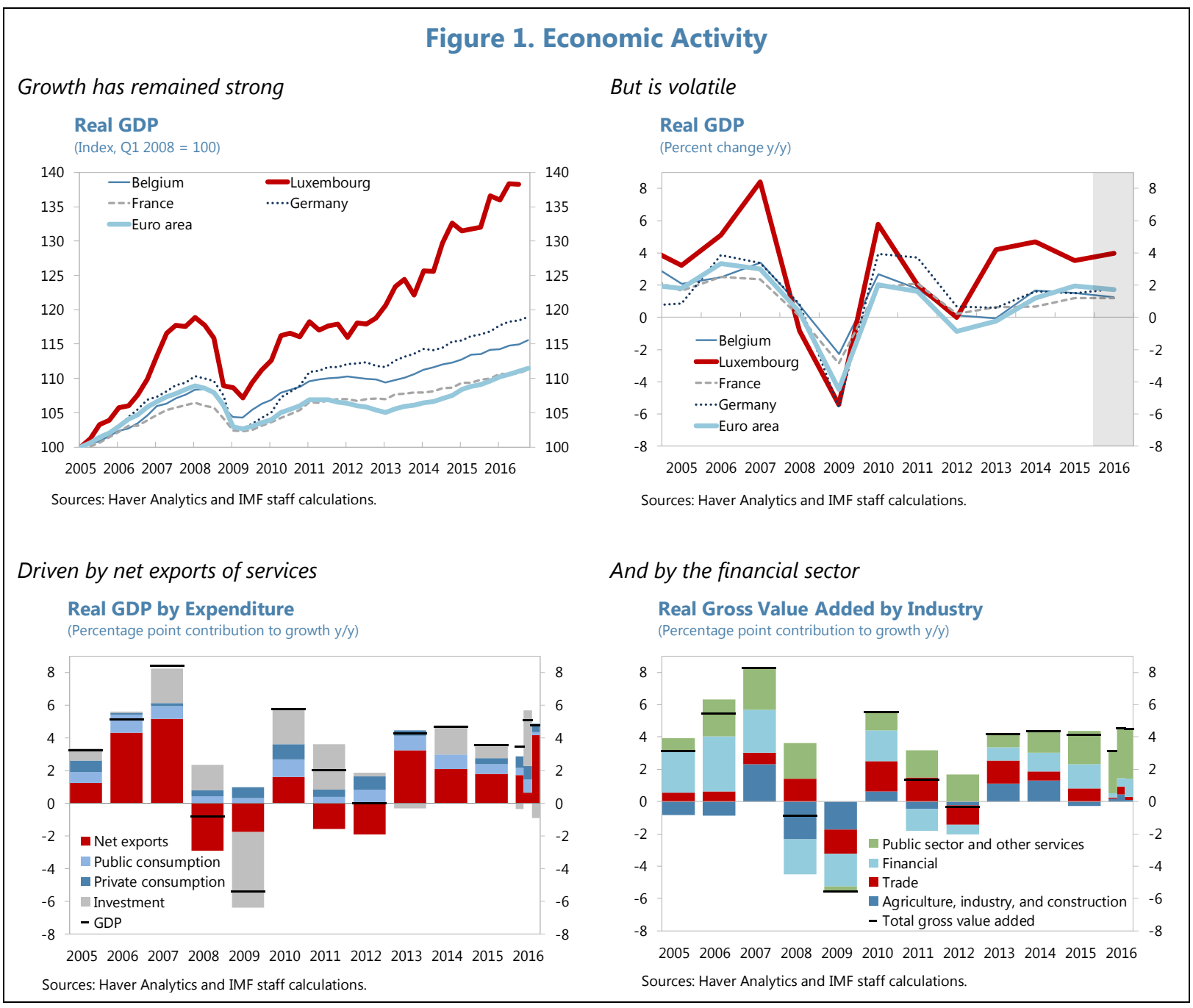




\section{RECENT DEVELOPMENTS}

5. Luxembourg's economic performance has remained strong in 2016, despite a volatile international environment. Net exports of financial services and consumption were the two largest contributors to real GDP growth estimated at 4 percent in 2016. Strong growth and active labor market policies have contributed to a reduction of the unemployment rate to 6.4 percent by end-2016. Headline inflation remained close to zero during the first 7 months of 2016, in line with euro area trends. With rising oil prices, inflation has rebounded later in the year, thereby triggering the wage indexation of 2.5 percent in January 2017.

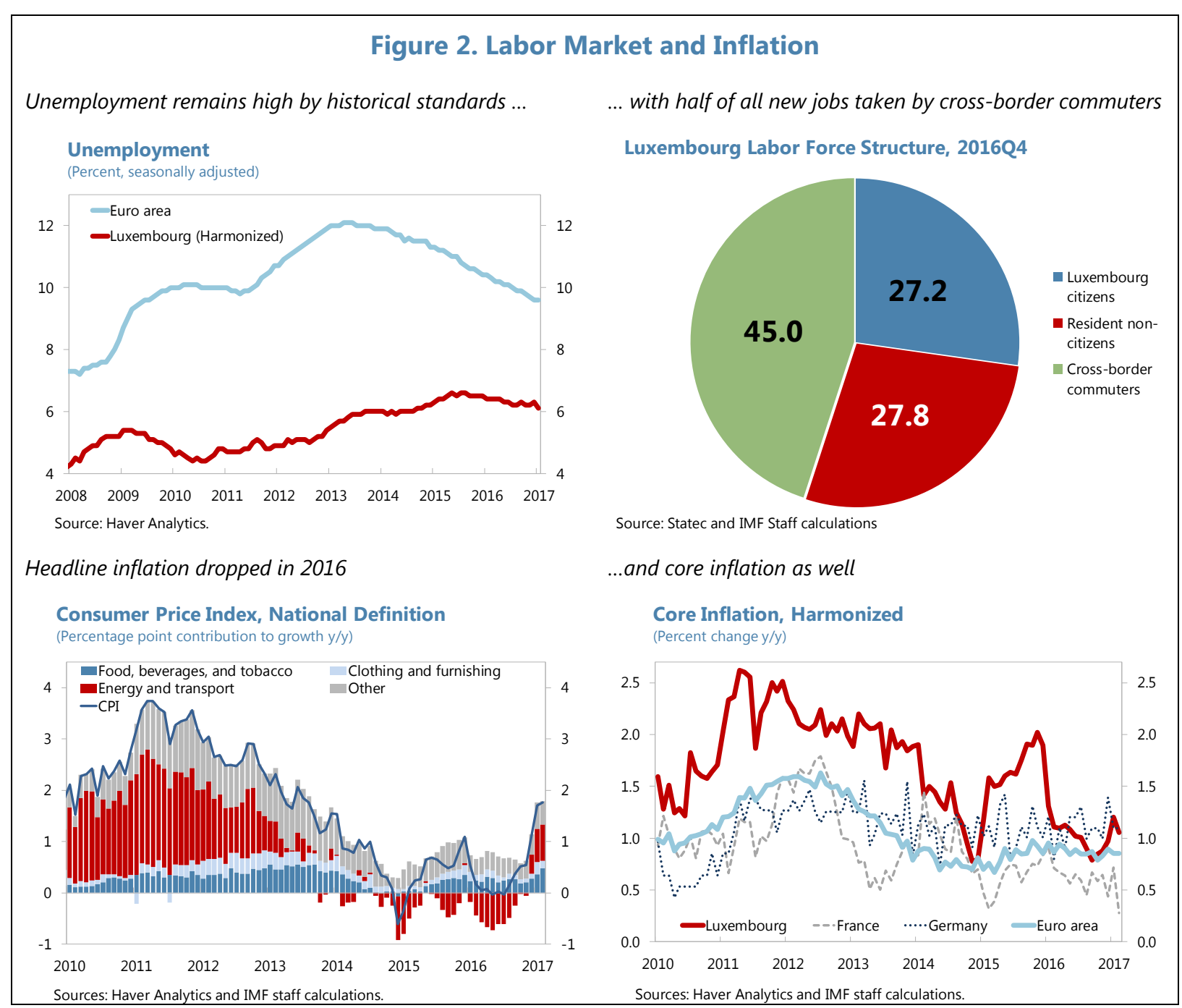


6. Financial sector developments. The performance of financial sector is an important driver of real GDP growth (it accounts for $1 / 4$ of GDP). Despite bouts of volatility in international financial markets, the financial sector has remained profitable.

- Investment fund industry. Staff econometric analysis shows that funds' assets are a driver of financial sector gross valued added, and therefore of real GDP growth, and that the valuation of these assets is driven by global capital market performance. Redemptions exceeded inflows in 2016:Q1 by $€ 15$ billion but net inflows experienced a rebound in 2016:Q2-4 with €114 billion. Strong negative valuation effects of $€ 95$ billion in 2016:Q1 were followed by positive valuation effects of $€ 191$ billion in 2016:Q2-4.

- Banking system. In the first three quarters of 2016, net income of banks declined by 1.4 percent year-on-year, as commission and fee income declined from the strong performance in 2015, while net interest margins increased by 7 percent. In 2016, credit to the non-financial private sector grew by 8.7 percent, among which credit to households grew by 6 percent. ${ }^{1}$

Capitalization and liquidity buffers remained strong in the banking system. While banks started to implement the Savings Directive, the Banque et Caisse d'Epargne de l'Etat reached an out-ofcourt settlement of $€ 14$ million with the German authorities for allegedly having helped savers evade taxes in the past.

\section{EC probes challenge Luxembourg's authority to provide selective tax advantages to} multinational companies. The authorities disagreed with the EC decision that the advance tax ruling (ATR) of Fiat involved improper state aid and appealed it in court. Meanwhile, the EC continues to investigate the ATRs of Amazon and MacDonald's. In September 2016, it opened an investigation of the ATR for GDF-Suez Group (now Engie), a French state-owned utility. In August 2016, the first "Lux-leaks" trial came to an end. While the two former PwC employees were sentenced to prison with reprieve, the action of the whistleblowers was recognized by the court to be in the general interest and they have on appeal received reduced sentences in March 2017.

\footnotetext{
${ }^{1}$ In 2015, specialized financial firms were reclassified as nonfinancial firms, which resulted in a level increase in credit to the nonfinancial private sector.
} 
Figure 3. Financial Sector Developments

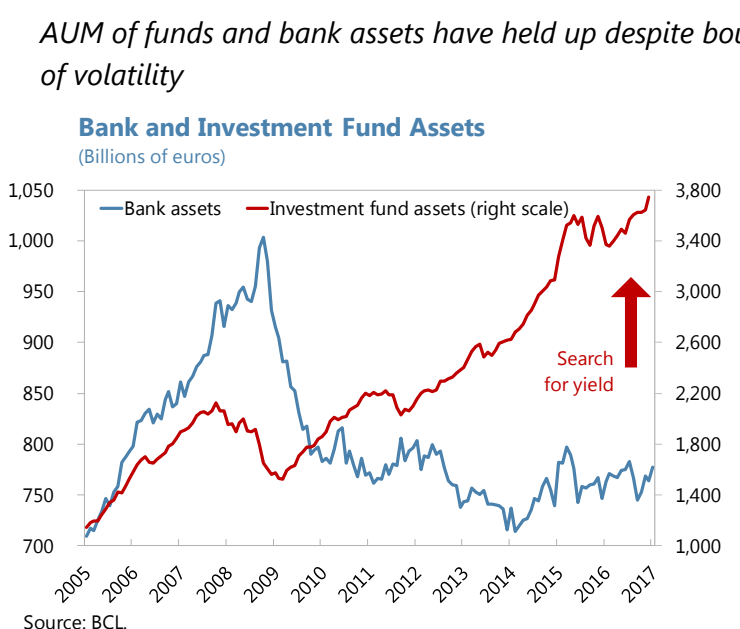

Fund management has lifted banks' net income

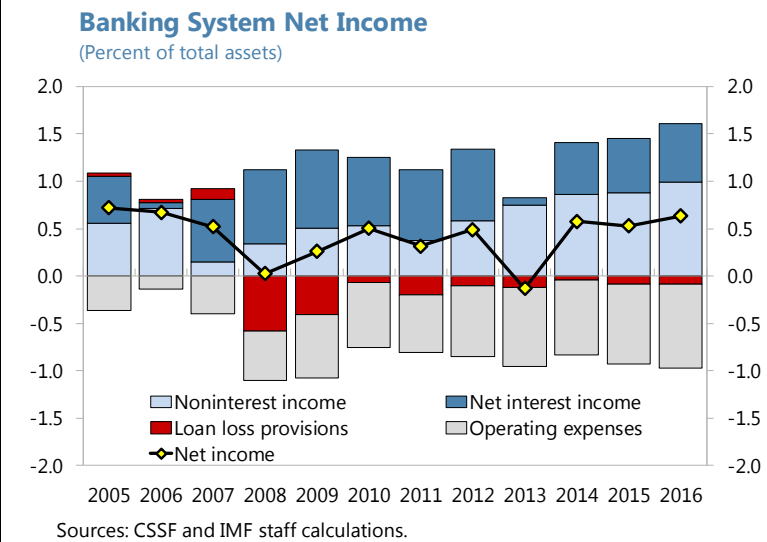

Net inflows in IF have been stable despite swings in asset values

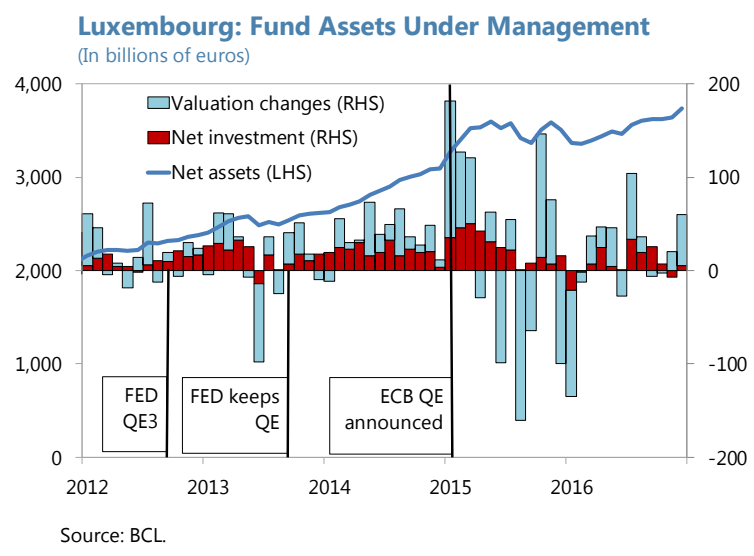

Domestic credit growth stable but statistical reclassifications

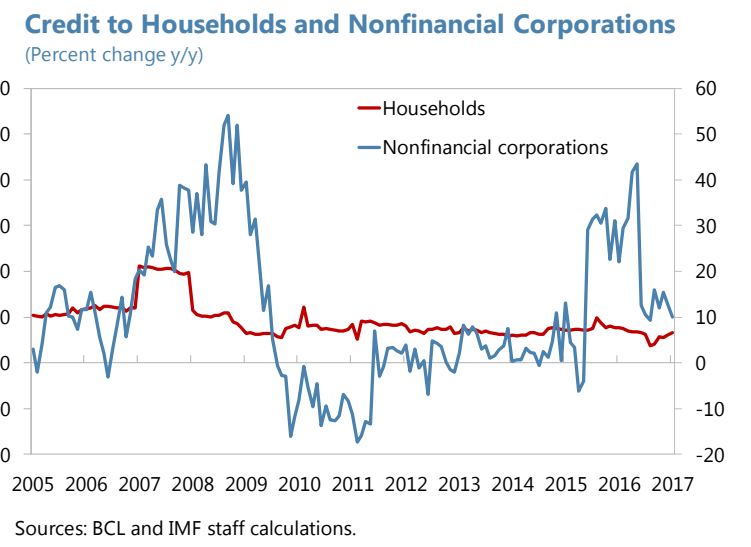

\section{Luxembourg is taking steps to implement the international and EU tax transparency} and anti-tax avoidance agenda but the country remains exposed to reputational risks

(Appendix I). Luxembourg participates in the OECD/G20 BEPS project and the OECD Global Forum on tax transparency assesses Luxembourg as being largely compliant. In January 2017, Luxembourg included tax crimes as predicate offenses to money laundering (as required by the AML/CFT standard), and, together with 30 other OECD countries signed agreements for the automatic exchange of ATRs and advance price agreements (APAs), and has joined the EU-wide automatic exchange of ATRs effective from 2017. In December 2016, the Ministry of Finance published a circular on the tax treatment of intra-group transfers (transfer pricing) aimed at implementing BEPS recommendations. The authorities intend to transpose into law the EC Anti-Tax Avoidance Directive (ATAD) which was issued in July 2016, building on BEPS recommendations. In addition, in October 2016, the EC launched a proposal for an EU Common Consolidated Corporate Tax Base (CCCTB) that aims to establish an integrated corporate tax regime. According to the Ministry of Finance the total number of ATRs, APAs included, reached 599 in 2015 but declined to 459 in 2016. 
Figure 4. External Sector Developments

The current account has narrowed moderately as a result of rising net factor payments

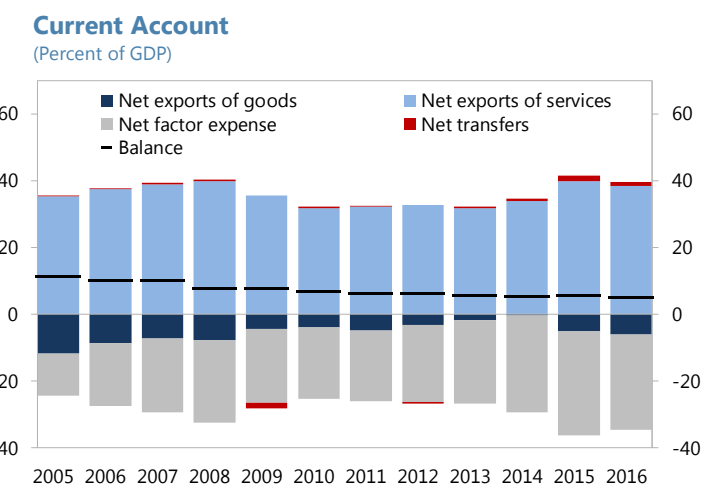

Sources: Haver Analytics and IMF staff calculations.

The net IIP is volatile

International Investment Position (Percent of GDP)

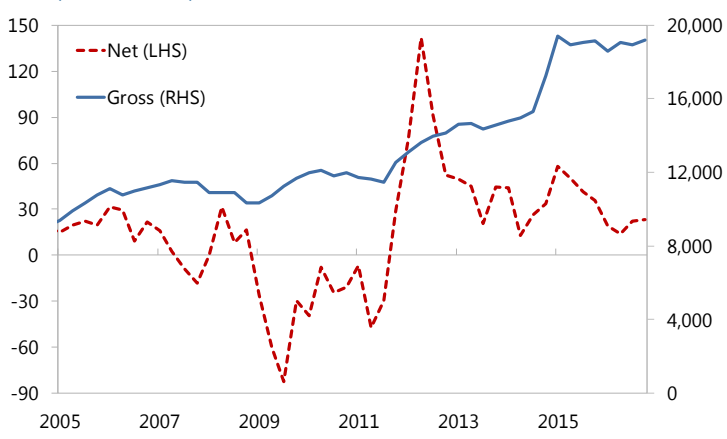

Sources: Haver Analytics and IMF staff calculations.
... even as net exports of financial services have remained strongly positive.

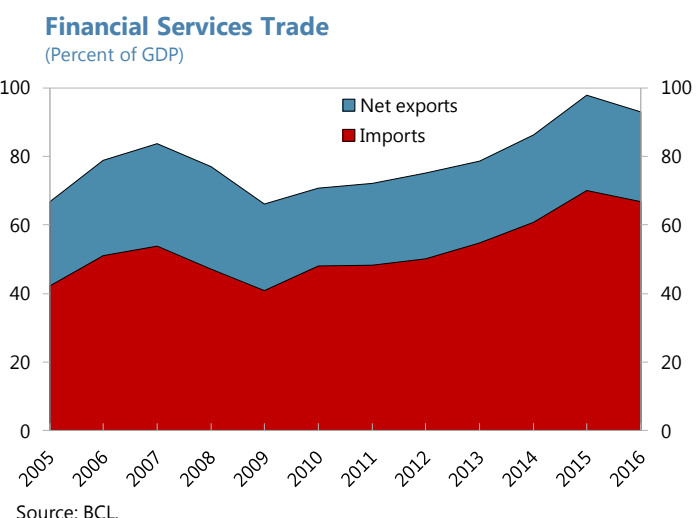

While the huge gross IIP reflects mainly multinationals treasury operations and investment funds activity

IIP Structure: Assets (outer) and Liabilities (inner), 2016 (Billions of euros)

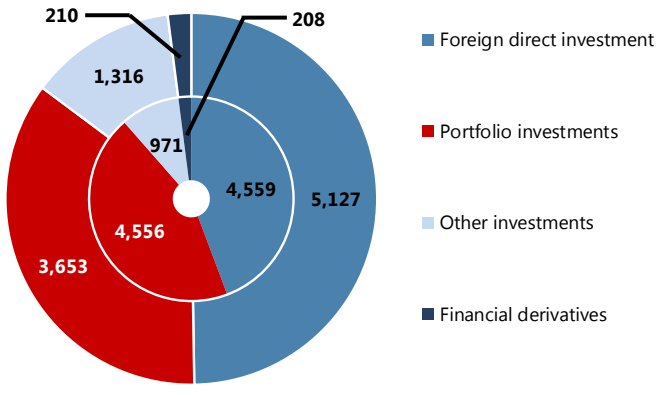

Sources: Haver Analytics and IMF staff calculations.

\section{OUTLOOK AND RISKS}

9. The medium-term growth outlook remains solid, underpinned by robust domestic demand and net exports. GDP growth should gradually decline to about 3.7 percent in 2017 and

\begin{tabular}{|c|c|c|c|c|c|c|c|c|c|}
\hline \multicolumn{10}{|c|}{ Luxembourg: Baseline Macroeconomic Framework, 2014-22 } \\
\hline & 2014 & 2015 & 2016 & 2017 & 2018 & 2019 & 2020 & 2021 & 2022 \\
\hline & & & Est. & \multicolumn{6}{|c|}{ Projections } \\
\hline Real GDP (percent change) & 4.7 & 3.5 & 4.0 & 3.7 & 3.5 & 3.3 & 3.1 & 3.1 & 3.0 \\
\hline Domestic demand (percentage pt. contribution to growth) & 2.6 & 1.7 & 1.7 & 3.1 & 2.5 & 2.2 & 2.0 & 2.0 & 1.9 \\
\hline Net exports (percentage pt. contribution to growth) & 2.0 & 1.7 & 2.3 & 1.0 & 1.0 & 1.1 & 1.1 & 1.1 & 1.0 \\
\hline CPI inflation (percent change) & 0.7 & 0.1 & 0.1 & 1.4 & 1.3 & 1.7 & 1.9 & 2.0 & 2.0 \\
\hline General government balance (percent of GDP) & 1.5 & 1.6 & 1.7 & 0.3 & 0.1 & 0.0 & 0.0 & 0.0 & 0.0 \\
\hline General government gross debt (percent of GDP) & 22.7 & 22.1 & 22.6 & 23.2 & 23.5 & 23.2 & 23.0 & 22.8 & 22.9 \\
\hline Unemployment rate (percent, national definition) & 7.1 & 6.8 & 6.4 & 5.9 & 5.7 & 5.6 & 5.5 & 5.4 & 5.3 \\
\hline Current account balance (percent of GDP) & 5.1 & 5.2 & 4.8 & 5.1 & 5.1 & 5.4 & 5.5 & 5.6 & 5.8 \\
\hline Nonfinancial private sector credit (eop, percent change) & 4.9 & 15.7 & 5.7 & 5.1 & 3.9 & 3.4 & 2.7 & 2.8 & 2.6 \\
\hline
\end{tabular}


to its trend rate of about 3 percent thereafter. ${ }^{2}$ The moderate but steady contribution of net financial services exports to growth over the medium term reflects Luxembourg's function as a financial hub and the gradual recovery in the euro area. With the resumption of wage indexation and higher energy prices, inflation is expected to pick up to 1.3 percent in 2017, and reach 2 percent over the medium term.

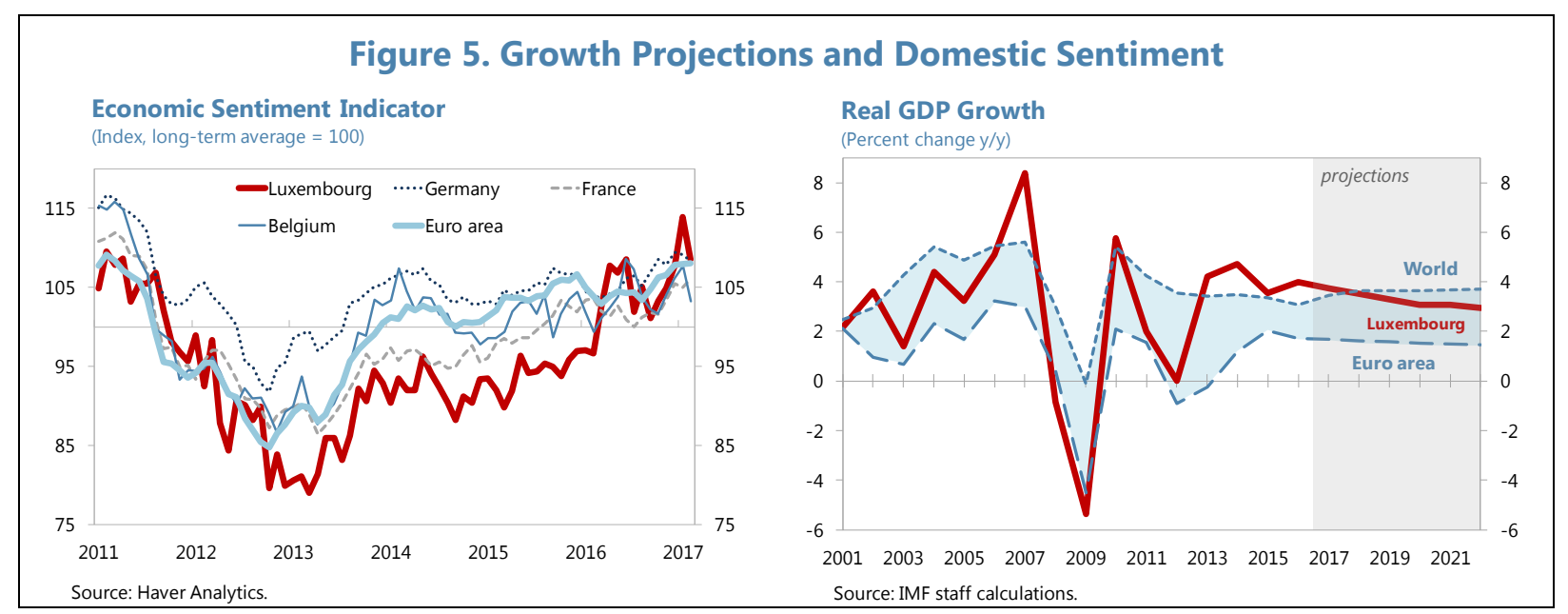

\section{Luxembourg's external position is projected to remain broadly in line with}

fundamentals. The current account surplus is expected to be close to 5 percent of GDP over the medium term, supported by a large surplus in services which is partly offset by net income payments abroad and a moderate negative goods balance. In view of Luxembourg's position as a financial center and as a hub for multinationals' treasury activities, the financial account displays very large gross inflows and outflows. With the projected current account surpluses, Luxembourg's positive net international investment position would gradually increase over time. Staff's External Balance Assessment (EBA-lite) indicates that Luxembourg's external position is broadly consistent with fundamentals, suggesting that its current account balance is close to its norm and the real effective exchange rate is slightly overvalued (Appendix II).

11. The changing international tax transparency and anti-tax avoidance environment is a challenge to Luxembourg. Related risks to Luxembourg's economic model and fiscal revenue are moderated by the pro-active approach of the authorities in adapting to the new tax transparency and anti-tax avoidance requirements. Eliminating selective tax advantages in all countries and creating a level playing field could accentuate Luxembourg's other competitive advantages such as its triple AAA rating and qualified labor force.

\section{Other risks include a retreat from cross-border integration, policy uncertainty and} financial market volatility affecting the financial system, weaker-than-expected growth in the euro area, and further security dislocation. Financial volatility would be triggered by a retreat from cross-border integration leading to protectionism and economic isolationism, by reduced

\footnotetext{
${ }^{2}$ We estimate potential output using a HP filter because Luxembourg is a small country with volatile economic macroeconomic indicators that heavily depends on its financial sector.
} 
global and regional policy collaboration, or by policy uncertainty and divergence-with two-sided growth risks and difficult to predict policies in the U.S., and uncertainty associated with negotiating post-Brexit arrangements and upcoming elections in Europe. A reassessment of underlying risks to policy fundamentals in global asset markets could lead to a sharp adjustment of asset prices and a decompression of term premia adversely affecting Luxembourg's investment funds and their links to the banking system, which would be conduits of international spillovers. The impact on the banking system could be mitigated, in part, if Luxembourg becomes the recipient of safe havens inflows. Luxembourg also remains vulnerable to lower-than-expected growth in Europe and challenges to the euro area architecture, and a renewed surge in refugees.

\section{Authorities' views}

\section{The authorities agreed that a retreat from cross-border integration and policy} uncertainty at the global level is a downside risk to Luxembourg, which might have negative effects through the financial system and activities of multinationals. They considered that it is crucial for Luxembourg to maintain sound policies and diversify the economy to increase its resilience to external shocks. While Brexit poses a downside risk to the EU, Luxembourg's net imports of financial services from the UK would be less affected, and there could be positive spillovers as Brexit could lead to a reallocation of some financial sector activities to Luxembourg. The authorities agreed with staff that Luxembourg's external position remains broadly in line with fundamentals.

\section{POLICY DISCUSSIONS}

\section{A. Financial Sector}

14. The financial system of Luxembourg, in which the government plays an important role, is strongly interconnected domestically and internationally, making Luxembourg a recipient and transmitter of shocks (Box 1). The financial sector accounts for 25 percent of GDP, 10 percent of employment and 18 percent of tax revenues. There are also very strong macrofinancial linkages between domestic institutional sectors, notably among banks, investment funds, "other financial institutions" and corporations. In recent years, the oversight of the financial system was significantly improved (Appendix III). The Ministry of Finance plays a leading role in setting strategic choices, as well as proposing legislation, including by chairing the Systemic Risk Committee (CRS) and the regulators' non-executive boards (Commission de Surveillance du Secteur Financier, CSSF, and Commissariat aux Assurances, CAA). ${ }^{3}$ The government has stakes in four of the five domestically-oriented credit institutions, with assets accounting for 225 percent of GDP (120 percent of GDP when weighting assets by the stakes of the State in each bank). ${ }^{4}$

\footnotetext{
${ }^{3}$ Some of the regulatory powers have shifted to the ECB since the creation of the SSM.

${ }^{4}$ The Banque et Caisse d'Epargne de l'Etat, has historically been a fully state owned bank, while direct state participations in two other banks are a legacy of resolution during the Global Financial Crisis.
} 


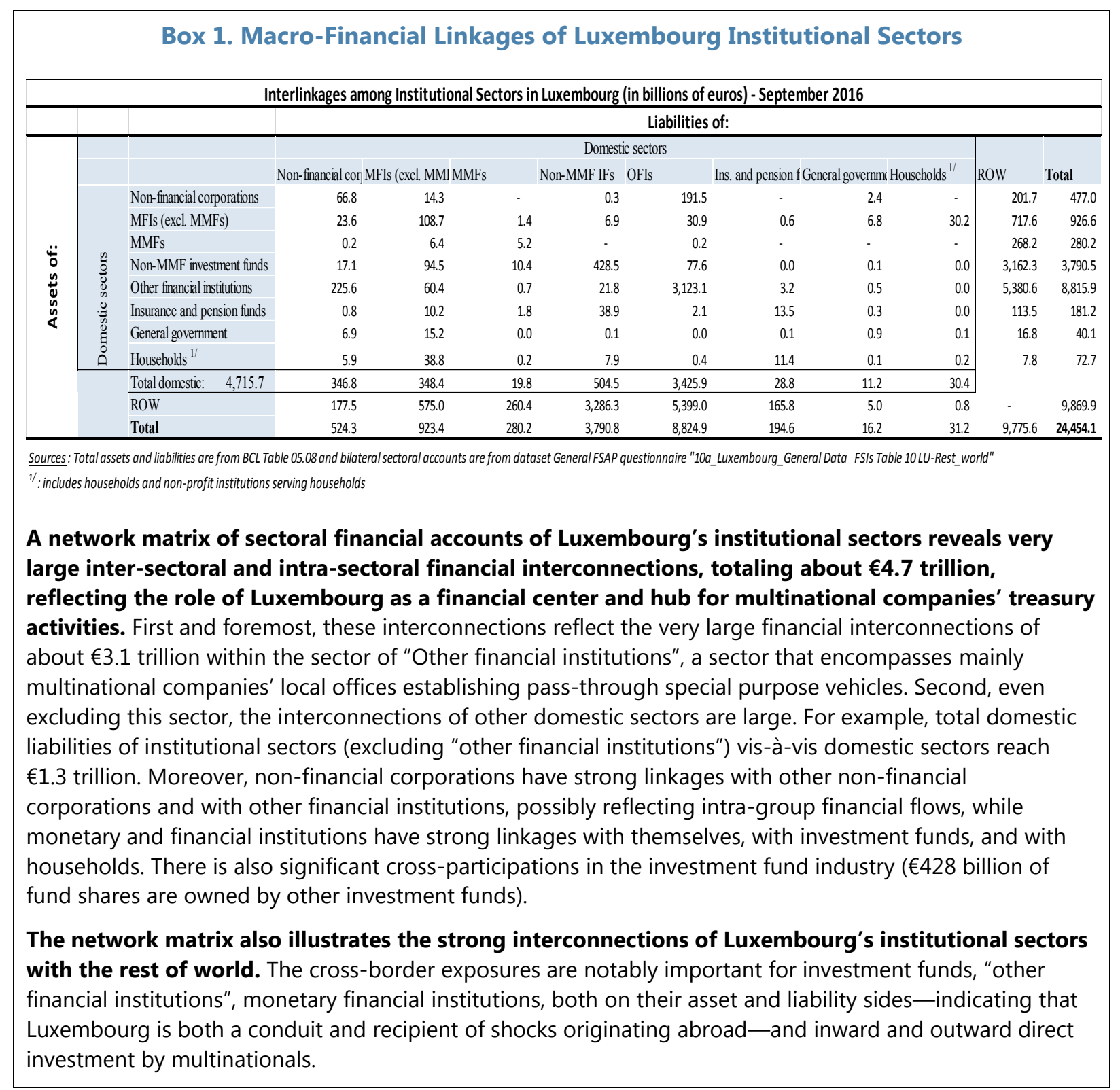

15. Vulnerabilities resulting from interconnections via the investment fund industry could be ignited by materializing global risks and transmit shocks in global asset markets, including through the industry's linkages with banks. In a downside scenario, an unexpectedly large redemption shock (likely due to a spike in global risk aversion) affecting investment funds may result in cash deposits held with some Luxembourg banks to be withdrawn, causing a liquidity shock, while some foreign markets could be subject to fire sales from asset managers. A large and sustained shock to investment fund assets under management would impair bank profitability through a decline in net fee and commission income. 


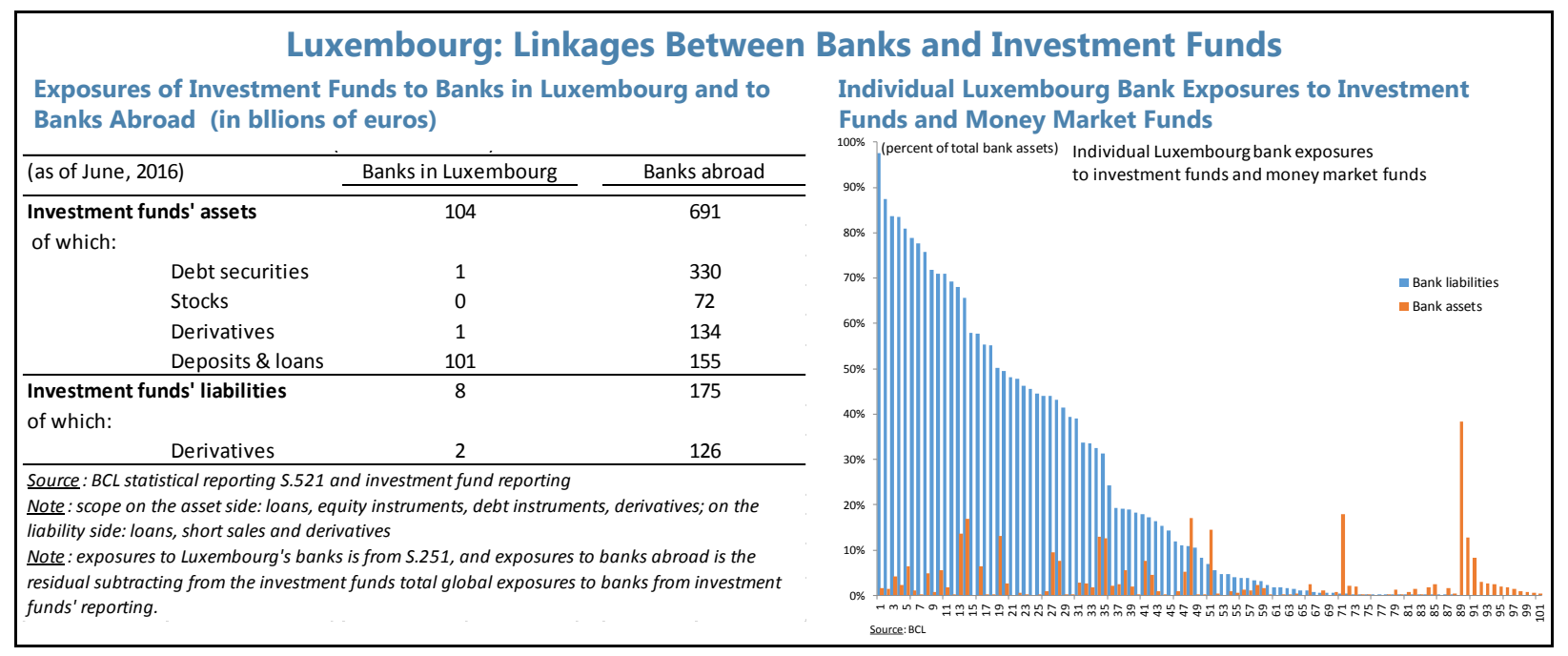

16. While investment fund supervision is conducted prudently, the supervisory regime and risk monitoring should be further strengthened, in keeping with Luxembourg's role as a preeminent global financial center and as recommended in the 2017 FSAP (Appendix IV). The frequency of on-site inspections should be increased, and comprehensive inspections introduced. As stress tests performed in the 2017 FSAP found resilience at the aggregate level but liquidity and concentration risks in some bond funds, risk monitoring should continue to emphasize monitoring of liquidity, concentration, and market risks in vulnerable segments, as well as risks related to investment fund-bank linkages. A greater intensity in inspections would help to ensure that the extensive use of delegated activities, including portfolio and risk management, is appropriately monitored. The authorities should ensure that depository banks are sufficiently independent from the investment funds they oversee and engage with regulators in jurisdictions where delegated activities such as portfolio and risk management are prominent. The CSSF should issue guidance to the industry on the use of liquidity management tools and on the scope, frequency and modalities of liquidity-based stress tests and, as part of an intensified supervisory approach, should develop the capacity to undertake system-wide stress tests of investment funds (consistent with Financial Stability Board (FSB) proposals, work-streams at the European Systemic Risk Board (ESRB), and similar efforts underway elsewhere).

\section{Luxembourg's banks are generally resilient to solvency and liquidity stress tests, with} pockets of vulnerabilities in a few banks, as found in the 2017 FSAP. Bank profitability, capital, liquidity and asset quality have remained high (Table 6). Net interest margin compression has been less problematic in Luxembourg than elsewhere in Europe due to the banking industry's increasing reliance on fee and commission income derived from private banking and from investment fund management and depository activities. Internationally oriented banks are exposed to two main sources of risk. First, deposits accumulated from private wealth management and investment fund activities are frequently 'upstreamed' to foreign parents. As a result, Luxembourg-domiciled bank subsidiaries may be exposed to maturity and currency transformation risk at the parent level where oversight by the Luxembourg authorities may be limited. Second, banks could be exposed to adverse liquidity and profitability shocks from severe stress in the investment fund industry. In the event of severe stress, foreign currency mismatches could arise and cash withdrawals from funds could be significant. 


\section{A number of additional measures would help to safeguard stability of the banking} system, in line with the recommendations of the 2017 FSAP. More frequent on-site inspections, particularly for foreign subsidiaries availing of the waiver to intragroup large exposure limits, should be put in place, and banks should be required to periodically justify their continued eligibility for the waiver. Also, in line with the recommendations of previous consultations, the authorities should take the initiative to reinforce the oversight of non-bank holding companies of banks to improve risk monitoring, while continuing to advocate for a coordinated approach at the European level.

\section{Banks' exposure to the real estate market is a risk to watch closely (Box 2). For the} handful of banks that lend domestically, mortgage loans amounted to $€ 26.1$ billion in January 2017, or about $481 / 2$ percent of GDP. The government's stake in four banks holding most mortgage risk raises the potential for spillovers to the sovereign in a downside scenario. On November 28, 2016, the ERSB issued a risk warning to Luxembourg and seven other EU countries, highlighting the existence of medium-term vulnerabilities related to the interaction between rising indebtedness and ability of households to repay their mortgage debt, and the price dynamics of residential real estate. ${ }^{5}$ Balanced against these vulnerabilities, however, are the modest share of mortgages in domestically oriented bank assets (16 percent), the low average loan-to-value ratio (52 percent), and high overall household net worth (financial assets exceed household debt by 2.4 times).

\section{Box 2. Risks in The Real Estate Market}

Rising house prices. Against the backdrop of an expanding population, low interest rates and binding supply side constraints, residential real estate price-to-income ratios in Luxembourg have become elevated by historical and global standards (Figure 6). After a marginal decline in 2009, nominal home prices have since increased 30 percent (or 22 percent in real terms), a period over which real disposable income of the local population has been flat, though GDP and employment growth continued.

Supply bottlenecks make housing less affordable to residents. Analysis based on an empirical model of real house prices suggests that real house prices were overvalued before the global financial crisis because house prices were growing significantly faster than a trend (explained by population growth). Since then, their evolution has become more aligned with real GDP and population growth, in spite of the flat disposable income of the resident population while the low interest rate environment has improved their borrowing capacity. This analysis suggests that supply has only partially adjusted to the rapid growth of demand.
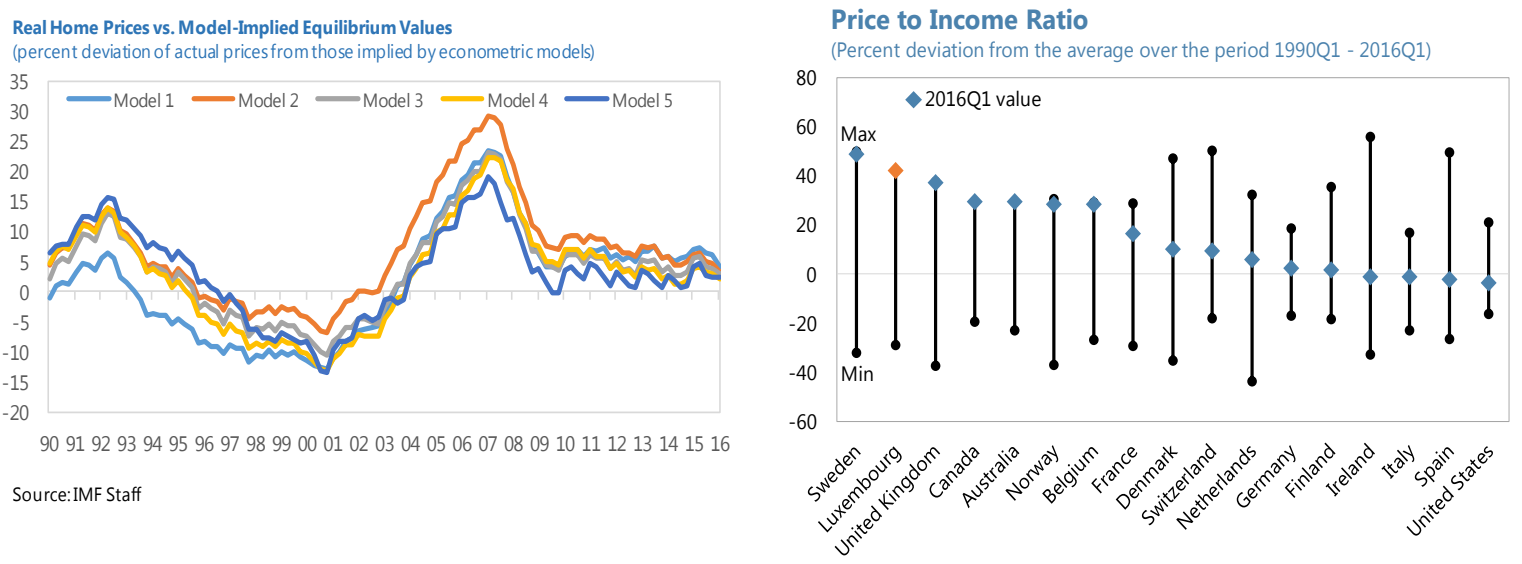

\footnotetext{
${ }^{5}$ ESRB Warning of the European Systemic Risk Board of September 22, 2016 on medium-term vulnerabilities in the
} residential real estate sector of Luxembourg: https:/www.esrb.europa.eu/news/pr/date/2016/html/pr161128.en.html. 


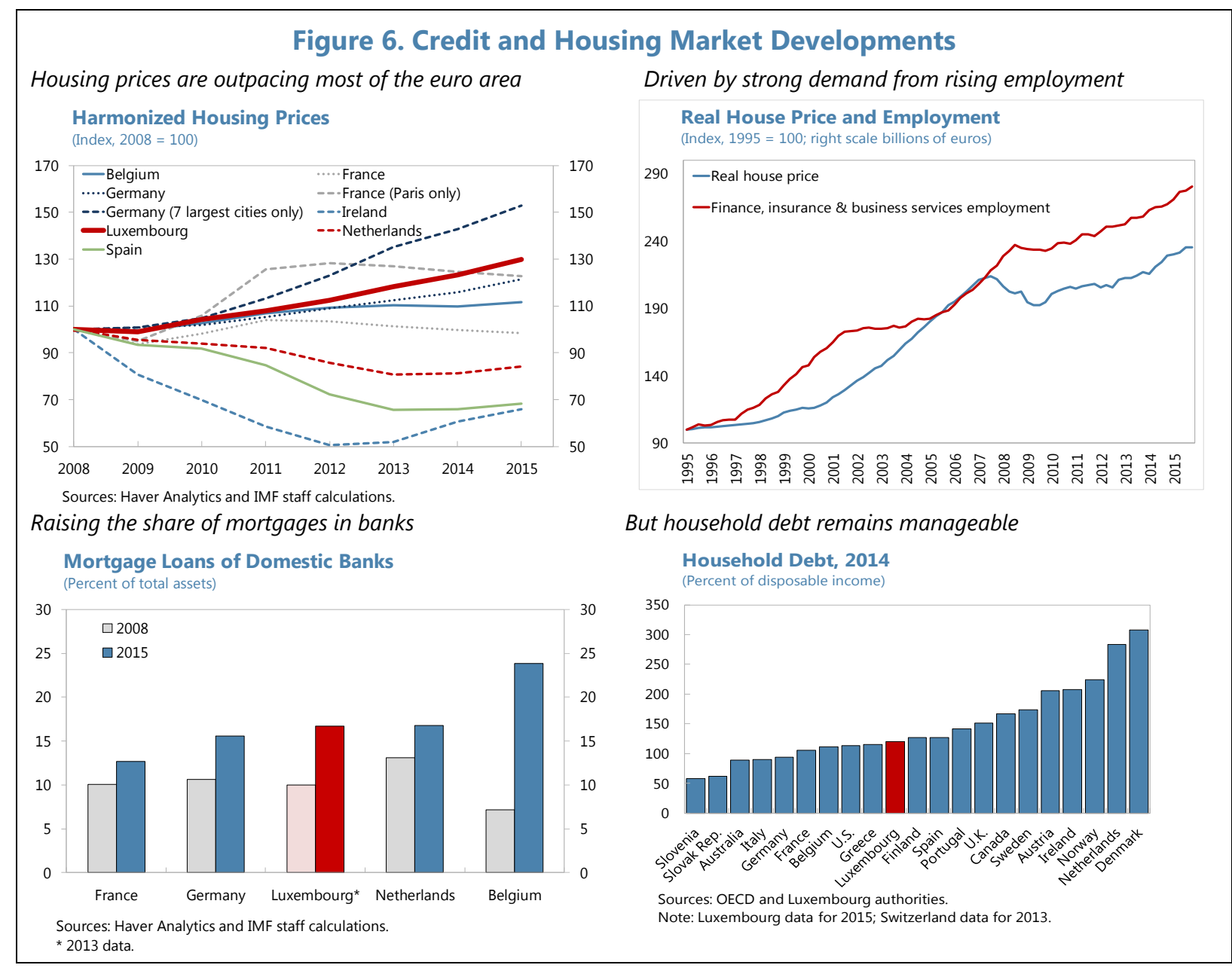

20. The authorities should continue to monitor risks in the real estate market, and take further actions if needed (2017 FSAP). The authorities have shown a willingness to use macroprudential measures to discourage riskier lending practices and strengthen buffers in the banking system. ${ }^{6}$ On December 23, 2016, the authorities transposed the EU Mortgage Credit Directive into law, thereby strengthening consumer information requirements, obligations to assess creditworthiness, and establishing an EU passport for credit intermediaries compliant in their home state. In light of rising risks, the impact on housing demand of the recent enhancement of tax incentives for home ownership should continue to be closely monitored, and data standards for the reporting of loan-to-value and debt-service-to-income ratios harmonized across banks to facilitate meaningful comparisons. Additional actions may be required if price and indebtedness trends continue to outpace income, potentially as a result of the impact of the tax reform on demand,

\footnotetext{
${ }^{6}$ These measures have included, since 2012, higher risks weights of 75 percent under the standardized approach for mortgages where loan-to-value ratios exceed 80 percent; stricter stress test requirements for IRB banks' mortgage books; pillar II capital add-ons; and, since August 2016, a risk weight floor of 15 percent for IRB banks' exposures to domestic real estate.
} 
including limits on loan-to-value and debt-service-to-income ratios, and measures to ease supply constraints. The CSSF should also work closely with the ECB to ensure households are included in the current euro area registry initiative. ${ }^{7}$

\section{Several cross-cutting themes may require further policy actions in the context of increasing size and complexity of the financial system and regulatory demands (2017 FSAP):}

- While the newly established macroprudential oversight framework is functioning well in practice, it could be strengthened. The leading role of the $B C L$ should be enshrined into law. The CRS, the $\mathrm{BCL}$ and the CSSF should continue to strengthen risk-based monitoring of the residential real estate market and the investment fund industry, and close remaining related data gaps. The macroprudential toolkit should be expanded by providing legal basis to borrower-based tools related to real estate lending, and the effectiveness of liquidity management tools in the investment industry should be assessed.

- Resolution planning requires further work while contingency arrangements should be put in place. Resolution planning should be accelerated for the most significant banks. Further guidance from the Single Resolution Board is needed to strengthen resolution plans, including by developing the sale of business and bridge bank tools, ensuring adequate liquidity funding in resolution, and taking into account large intragroup exposures and the impact of the potential exclusion of certain non-retail deposits (e.g., of investment funds) from the scope of bail-in. While the $B C L$ has an ELA framework in place, contingent funding arrangements in foreign currencies should be pursued.

- Although prudential oversight works well in practice, risk-based supervision should be further strengthened, and resources of institutions in charge of financial oversight should be further increased. The operational independence and accountability of the CSSF and CAA should be enshrined in law as recommended by international standards and their Board members, as well as those of the $B C L$, should be bound by codes of conduct in line with best practices. $A$ formal framework should be introduced to govern the relationship between the government and banks with state involvement. More consideration should also be given to the imposition of regulatory and/or supervisory safeguards to financial stability that go beyond the minimum prescribed by European legislation, where such actions could be justified in light of the particular characteristics of Luxembourg's financial system, to protect the supervisors' hard-earned reputational integrity.

22. Clearstream (CBL) is assessed by the 2017 FSAP as generally offering a safe and efficient system for the clearing, settlement and custody of securities transactions, although further risk mitigation measures are warranted. The authorities are encouraged to continue engaging the ECB to designate $C B L$ as a Significant Institution under the Single Supervisory Mechanism, alongside Belgium's Euroclear Bank, in order to ensure consistent implementation of supervisory requirements.

\footnotetext{
${ }^{7}$ In the case of Luxembourg, a credit registry system would be particularly timely given the increase in household indebtedness attributable to upward trending mortgage growth.
} 


\section{The capitalization of the $\mathrm{BCL}$ should be} strengthened. The comprehensive net worth of the central bank remains important from a risk management perspective, also allowing the $B C L$ to deal with various contingencies. An agreement between the government and the $\mathrm{BCL}$ should be reached and implemented swiftly, and the BCL's capital-to-asset ratio should over time converge to a level similar to that in other euro area central banks.

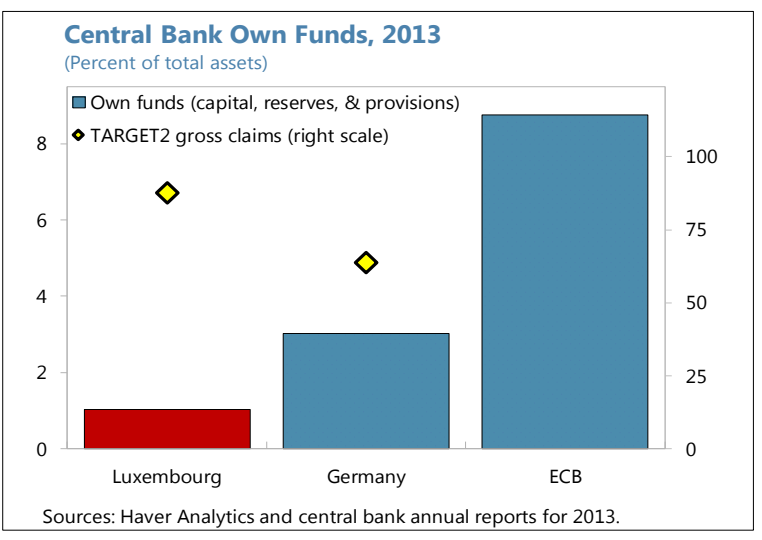

\section{Luxembourg is addressing its anti-money laundering and combating the financing of} terrorism challenges. The government's recent push for tax transparency constitutes a major change. The priority for the authorities should be ensuring that the ongoing National Risk Assessment adequately focuses on the specific risks related to tax evasion, and trust and company services providers across the range of relevant professions. The authorities should also provide adequate guidance to all private-sector reporting entities, including those not supervised by the CSSF, to support the effective implementation of suspicious transactions reporting requirements with respect to the new tax offenses that came into force on January 1, 2017.

\section{Authorities' views}

25. The authorities appreciated the work done under the 2017 FSAP, and were planning to follow up on most recommendations. They were generally supportive of recommendations on the oversight of the financial sector, including for nonbank holding companies and for investment funds and their linkages to banks. The CSSF has already produced a note on linkages between investment funds and banks, indicating that banks could withstand a sizable redemption shock from investment funds under certain assumptions. The CRS will also follow up with studies on bank-fund interlinkages and shadow banking. The authorities supported the recommendation on a code of conduct for regulators' boards, but disagreed on the recommendation regarding regulators' board composition and governance arrangements. They felt that their governance model is commensurate to the strategic importance of the financial center and comparable to that of other supervisory authorities. They did not think that the unanimity voting requirement at the CRS would impede decision making, but would consider to enhance the leading role of the central bank. The authorities underscored the importance of preserving the supervisory powers of host countries, including the possibility of imposing liquidity and loss absorption capacity requirements at the level of bank subsidiaries. On the real estate market, the authorities noted that action has been taken to build-up buffers in the banking system and acknowledged that medium-term vulnerabilities reside in the interactions between households' balance sheets and real estate valuations. They agreed that real estate valuations are broadly in line with economic fundamentals and that there might be an affordability problem for certain segments of the population, and supply-side constraints coupled with robust demand driven by demographic and economic growth. 


\section{B. Fiscal Policy}

\section{Fiscal performance is expected to have been stronger than foreseen in 2016, with a fiscal surplus projected at $\mathbf{1 . 7}$ percent of GDP, but staff expects the surplus to drop by} 1.4 percent in $\mathbf{2 0 1 7}$ and disappear thereafter as a result of the tax reform. The tax reform and continued past trends, including the further reduction in e-commerce VAT receipts and social contributions, would lower fiscal revenues by about 2.3 percent of GDP over the medium-term while spending would decline by 0.6 percent of GDP as a result of a moderately declining trend in social outlays. Luxembourg meets the new MTO of a structural balance of -0.5 percent of GDP. Luxembourg's public debt is among the lowest in the EU. The debt ratio is projected to be at about its 2016 level of 23 percent of GDP over the medium term, well below the authorities' ceiling of 30 percent of GDP, and to remain sustainable under different scenarios. However, in the scenario of a sizeable contingent liability shock, possibly related to the investment fund industry and exposures to the real estate sector, debt would strongly increase, but remain below 40 percent of GDP.

\section{Box 3. The Tax Reform of 2016}

The tax reform included in the 2017 budget contains a significant reduction in personal taxation and also in the corporate income tax rate from 2017:

- With the expiration of the temporary surcharge on personal income ( $1 / 2$ percent), the personal income tax brackets will be rebalanced to reduce the tax burden on all but the wealthiest households;

- Spouses will be allowed to file their taxes jointly or separately;

- Parental income tax benefits for non-resident and resident workers will be realigned;

- Home ownership incentives will be increased; and

- The statutory profit tax rate will be reduced by 3 percentage points to about 26 percent by 2018 .

The tax reform will increase domestic demand but the multiplier would be modest due to sizable import leakages. While some of the tax measures aim to increase the housing supply, the envisaged tax relief for home buyers would aggravate existing imbalances given that demand for real estate structurally outstrips supply, though the authorities assess the demand effect from this measure to be small. The government estimates that the fiscal cost of the reform would reach about 0.8 percent of GDP ( $€ 524$ millions) in 2017. The BCL estimates a fiscal cost of up to 1.7 percent of GDP ( $€ 944$ millions) on an accrual basis from 2018.

\section{While Luxembourg has fiscal space, domestic considerations do not warrant to use it} further at this juncture but to maintain strong buffers against revenue risks related to financial sector volatility and the international tax transparency agenda. With low public debt and a structural balance above the MTO, Luxembourg has fiscal space to respond if these risks materialize. At present, with a positive output gap, an external position broadly in line with fundamentals and rising inflation, it is appropriate for Luxembourg to broadly maintain fiscal balance and keep the public debt ratio at about its current level over the medium-term. However, in a downside scenario with a new recession, Luxembourg should participate if a European initiative of fiscal stimulus were launched. 


\section{The authorities should continue to implement the EU and international tax} transparency and anti-tax avoidance initiatives and address the possible fiscal revenue risks. Cross-border multinationals have very large assets in Luxembourg (according to the IMF Coordinated Direct Investment Survey, Luxembourg ranks second in the world in 2015, with $\$ 3.2$ trillion inward direct investment, excluding financial corporations' intragroup debt, or 57 times GDP). Greater corporate tax transparency and further anti-tax avoidance measures could diminish incentives to conduct business through Luxembourg and affect corporate income taxes, and potentially the labor market. ${ }^{8}$ In this context, further tax policy reform should aim at widening the corporate tax base, including by ensuring that the special tax regimes and transfer pricing arrangements are aligned with international and EU standards and rules, while lowering statutory tax rates in a revenue neutral manner. The decision to progressively phase out the IP Box tax regime from mid-2016 and the automatic sharing of information, including on ATRs are steps in this direction. The government should also promptly transpose the Anti-Tax Avoidance Directive into national law, and should develop contingency measures, including revisiting the low real estate valuation tax bases and enhancing green taxation, in case negative revenue risks materialize.

\section{Figure 7. Fiscal Policy Developments}

The general government has experienced a surplus

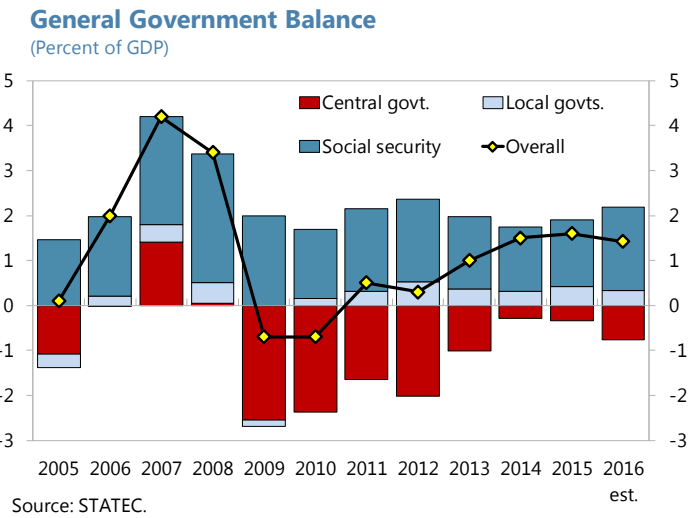

Expenditures and revenues have outpaced GDP

Revenues, Expenditures, and GDP

(Real index number, 2005=100)

150

$140-\begin{array}{lll} \\ -- \text { GDP } & \text { - Revenue excl. e-VAT } & \\ & & \end{array}$
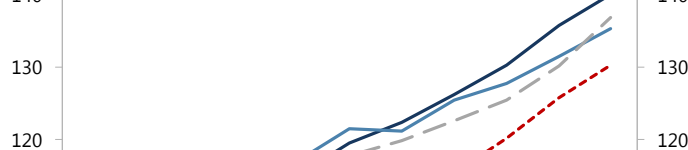

120

110

100

20052006200720082009201020112012201320142015

Sources: STATEC and IMF Staff calculations.
Allowing a stable positive net worth

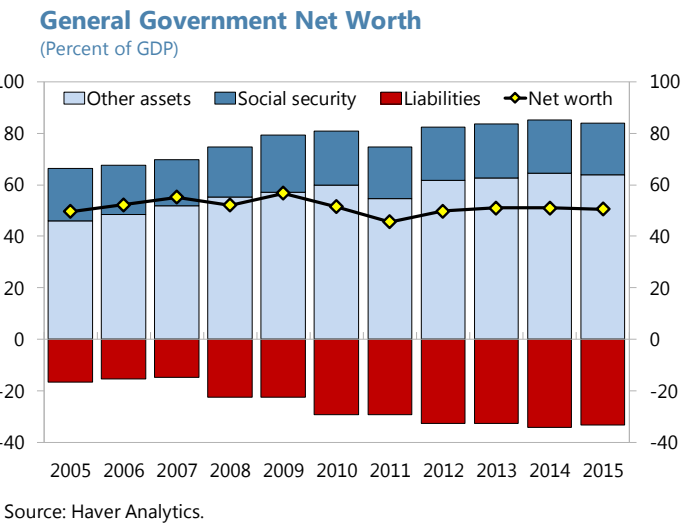

Partly reflecting a generous social benefit system

Social Benefits Per Head, 2014

(Euros)

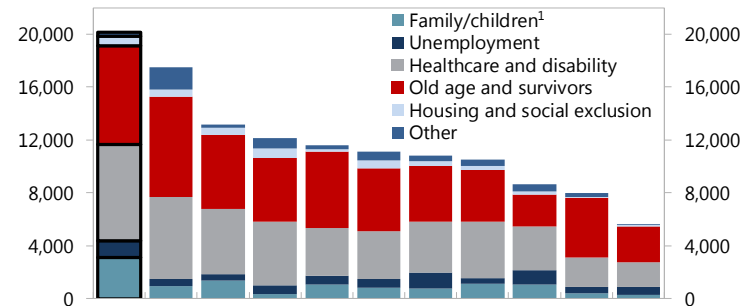

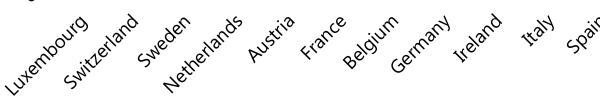

Sources: Eurostat and IGSS.

Adjusted for family benefits provided to cross border workers.

\footnotetext{
${ }^{8}$ Total corporate income tax revenue reached $4 \frac{1}{2}$ percent of GDP in 2015 . Tax revenue of some $1-1 \frac{1}{2}$ percent of GDP could be at risk, an amount which is similar to the 1.2 percent of GDP revenue loss in 2015 resulting from changing EU rules on allocating VAT from e-commerce.
} 
29. Continued reform of the pension system is advisable to ensure its viability over the long run. The financial statement published in 2016 shows that the pension system is currently projected to generate surpluses until 2023, but thereafter progressively use up the accumulated reserves. Population ageing is expected to increase pension expenditures (by 4-9 percent of GDP by 2060 , depending on the assumed population growth rate). Further pension reforms should be considered, to increase the effective retirement age, which at 61 years is low compared to Luxembourg's neighbors, including by reducing incentives for early retirement.

\section{Authorities' views}

30. The authorities considered that the tax reform will boost private consumption and investment, supporting domestic demand, in addition to the automatic wage indexation which also took effect in January 2017. They agreed that Luxembourg should maintain fiscal balance and stabilize the public debt to GDP ratio while preserving fiscal buffers for contingent exogenous shocks that may adversely impact the economy. The authorities were committed to complying with international transparency and anti-tax avoidance requirements. They are implementing the automatic exchange of information, including on advanced tax rulings (ATRs), starting this year through the adoption of common reporting standards. They also welcomed the EU Anti-Tax Avoidance Directive and are preparing its transposition into national law. The authorities believed that on a more level taxation playing field Luxembourg would benefit from its various comparative advantages, and that the revenue impact of these initiatives could be limited. While some companies may leave Luxembourg, others could expand their activities. While the implementation of these measures should result in a broadening of the tax base, the authorities will monitor carefully the impact on the competitiveness of Luxembourg and take appropriate actions if needed. The authorities have created a pension group, comprised of the social partners and of government, with the goal of providing recommendations for reform of the pension system before the 2018 elections.

\section{Structural Reforms and Diversification of the Economy}

31. In view of the risks to Luxembourg's economic model and to make it more inclusive, it is important to pursue efforts to foster the diversification of the economy to increase its resilience to shocks and to facilitate employment of vulnerable groups. Further expanding economic activity beyond the financial sector would also enhance broad-based job creation. The efforts of the government to promote new sectors of activity should be complemented by removing structural bottlenecks to economic activity, undertaking efficient public investment in infrastructure and in education, and further deepening labor market reforms to address inactivity traps in the context of skill mismatches and the generous unemployment and social benefits system. 
32. The state is taking an active role in setting strategic directions to further diversify the economy (Selected Issues Paper, Chapter 1). Luxembourg's economy lacks diversification relative to peers, and employment is concentrated: in 2015, about 30 firms accounted for 23 percent of total employment. To diversify the economy, the authorities actively promote development in a few priority sectors, including automotive components, eco-innovation, healthcare and biotechnologies, information and communication, materials and production, and space technologies. They champion Luxembourg's role as a logistical transit

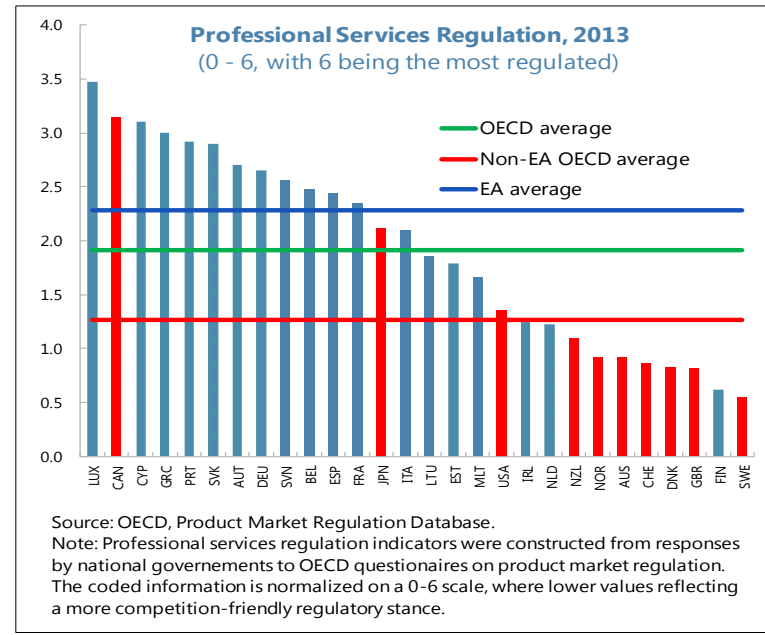
hub in the EU, have engaged in the pan-European project to build a supercomputer, and announced ambitious plans to create a legal framework for investing in mining asteroids. The Ministry of Economy is also actively developing the strategic direction of the Luxembourg's economy for the next decades. Structural reforms may help diversify the employer base by removing restrictions on private investment which slow down firm creation. Indeed, private investment is low by European standards, but this has been compensated by significant public investment in infrastructure, resulting in a high stock of public capital of good quality.

33. Luxembourg's product market remains more regulated in the non-financial service sector compared to neighboring countries. High restrictions on business services and retail investment slow down firm creation, contribute to the concentration of employment among larger firms, and may hamper domestic productivity and private investment. The main restrictions that should be addressed concern multidisciplinary limitations in the business services sector, as well as operational and establishment requirements in the retail sector. At the same time, bottlenecks that hamper housing investment should be reduced, and efforts aimed at providing social housing at affordable prices could be stepped up. The central and local governments should take measures to ease zoning requirements for construction and shorten the period required to obtain permits.

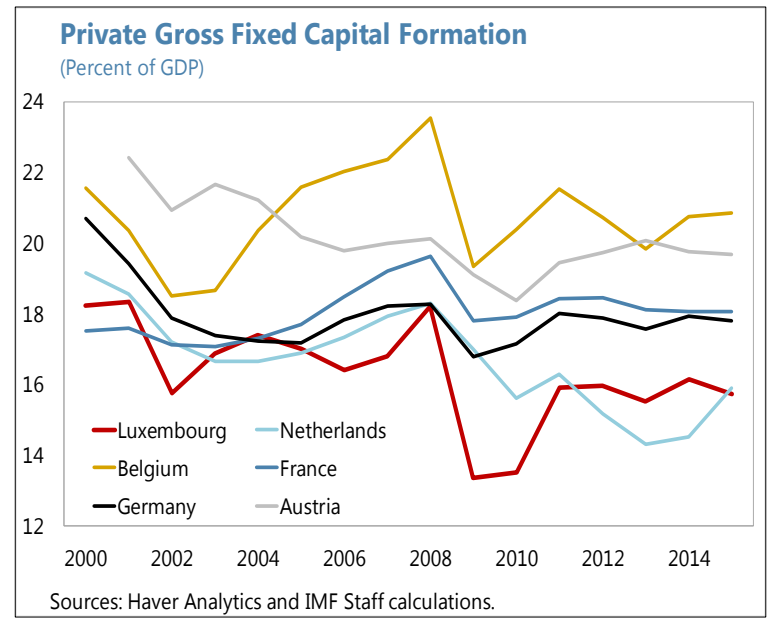


34. While unemployment is declining, reforms are needed to reduce inactivity traps and facilitate employment of vulnerable groups (Selected Issues Paper, Chapter 2). Skills mismatches are significant among the unemployed and the share of people who did not finish secondary school among the unemployed is 43 percent, more than double their share in the labor force. Innovative measures by the public employment service (ADEM) encompassing vocational training, apprenticeship programs, the Youth Guarantee Scheme, and the re-integration program of workers with reduced capacity have helped to reduce the unemployment rate and inactivity. However, an increasing share of new jobs created has accrued to cross-border workers while joblessness among residents remains stubborn. The new Accelerated Integration Program should facilitate employment of refugees. With wage indexation restarting in 2017, reductions in the longterm unemployment of low skill workers may face headwinds. The authorities should ensure that real wages remain in line with productivity and promote active labor market policies, including by expanding job search assistance and enhancing the apprenticeship system. Refocusing unemployment and social benefits to promote active job search and vacancy acceptance would help to reduce unemployment and inactivity traps. Of concern is also that while public spending on education is high, it does not translate into higher tests scores compared to other economies. Education reform should focus on upgrading education outcomes and improving the quality of vocational training in the context of a multilingual society with pupils coming from diverse backgrounds.

\section{Authorities' views}

35. The authorities stressed the proactive measures being taken to diversify the economy, particularly in several priority sectors such as ICT, bio technology, the space industry, and in the logistics sector. Among other initiatives, Luxembourg is taking an active role to promote the Third Industrial Revolution, based on a recent strategic study and ongoing working groups. They were open to consider alleviating regulations in the service sector and to explore possibilities to gradually expand housing supply, but noted that complex zoning restrictions involving municipalities would need to be taken into account. The authorities also agreed with staff that including vulnerable groups in the labor market remains challenging, but underscored the success of their policies in reducing unemployment. ADEM's personalized measures tailored to vulnerable groups and market needs in collaboration with employers, as well as re-integration initiatives to reevaluate medical conditions of workers with disability have helped to reduce inactivity and the unemployment rate. They believed that steps to provide language courses and other training to newcomers under the new Accelerated Integration Program should facilitate integration of refugees. While they recognized that the need to improve the educational system, they considered that only looking at overall test scores may miss-represent the challenges of their educational system due to its multi-language curriculum and large immigrant population. 


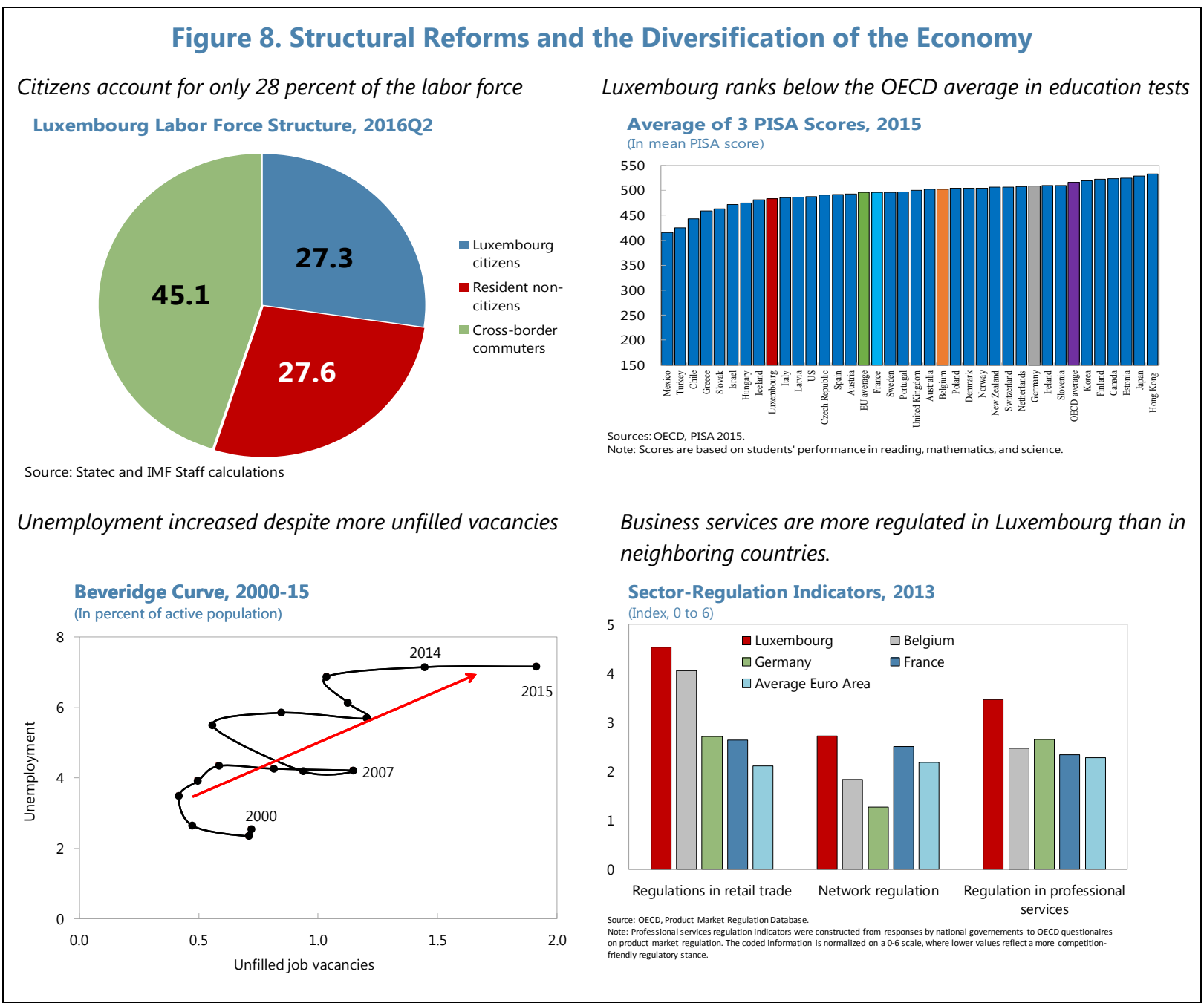

\section{STAFF APPRAISAL}

36. Growth and employment prospects remain strong but downside risks for the very open Luxembourg economy have increased. These risks arise from a possible global retreat from cross-border integration; policy uncertainty in the U.S. and associated with the outcome of elections in Europe and post-Brexit arrangements; and the potential impact of the international tax transparency and anti-avoidance agenda. Interconnections via Luxembourg's large investment fund industry could make it a conduit of global shocks in some scenarios. Other risks include weaker than expected growth in the euro area, and a renewed surge in refugees. Domestically, high and rising real estate prices and growing affordability issues could affect competitiveness and financial stability, while over the longer term the sustainability of the pension system is at stake. The external position is broadly in line with fundamentals and desirable policy settings. 
37. In view of these risks and the volatility of financial flows, the government should keep buffers for use in case of need. Fiscal space created by strong economic activity has been used in part for the tax reform. These risks, the vigorous expansion of activity and an already high level of public investment, argue for the government to stabilize the public debt ratio at about its current level, by targeting a small fiscal surplus in 2017 and a balanced budget over the medium term, broadly in line with the current policy stance.

\section{The government should continue taking steps to align its tax practices with new} international rules. In addition to enhancing tax transparency, it should transpose the EU Anti-Tax Avoidance Directive into national law. Further corporate tax reform should aim at widening the tax base by ensuring that any remaining special tax regimes are aligned with evolving international standards, while lowering statutory corporate tax rates in a revenue neutral manner. To address fiscal revenue risks, the government should develop contingency measures, including by revisiting the low real estate valuation tax bases and enhancing green taxation.

39. Continued reform of the pension system is advisable. The current surpluses are projected to disappear in the medium term, causing downward pressure on the fiscal position, and the accumulated reserves to be used up thereafter. Further reforms, including measures to increase the low effective retirement age, are needed to ensure the long-run sustainability of the system and preserve fairness across generations, while keeping Luxembourg an attractive place to do business.

40. A continued pivot towards risk-based supervision and further increase in resources for entities engaged in safeguarding financial stability are needed. Rising financial assets of a large and interconnected financial system and ever more complex international regulatory standards require a continued scaling up and deepening of financial sector supervision.

41. Intense supervision of banks' large cross-border exposures is required. In addition to the safeguards in place, more frequent on-site inspections should be introduced and banks should be required to periodically demonstrate their continued eligibility for the waiver to large exposure limits. The authorities should also take the initiative to reinforce the oversight of non-bank holding companies of banks to improve risk monitoring, while continuing to advocate for a coordinated approach at the European level.

42. The supervision and risk monitoring of investment funds should continue to be strengthened. The frequency of on-site inspections should be increased, comprehensive inspections introduced, and close engagement sought with regulators in jurisdictions where delegated activities such as portfolio and risk management are prominent. The authorities should provide guidance to the industry on liquidity risk management and develop capacity to undertake system-wide stress tests.

43. The new macroprudential policy framework appears to be working well and could be improved further. The legal framework could be enhanced by enshrining into law the leading role of the BCL. The CRS should further strengthen risk-based monitoring of the real estate market and the investment fund industry, while closing remaining data gaps. 
44. The real estate market should continue to be closely monitored, and further actions should be taken if upward price and indebtedness trends continue to outpace income. Various measures have appropriately discouraged riskier lending practices and have built buffers in the banking system. Measures should be taken to increase the supply of housing, while the merits of setting limits to loan-to-value ratios or debt-service-to-income ratios should be assessed.

45. Governance arrangements should be strengthened to ensure current good supervisory and financial sector policy practices are preserved well into the future. The operational independence and accountability of the CSSF and CAA should be enshrined in law as recommended by international standards. A formal framework should be introduced to govern the relationship between the government and banks with state involvement.

46. The efforts of the government to promote new activities should be complemented with product market reforms to support firm creation by removing restrictions and alleviating operational requirements in business services and the retail sector. The central and local governments should also take measures to maintain adequate public investment and infrastructure and increase the supply of housing, such as by easing zoning requirements for construction and shortening the period required to obtain permits.

47. To facilitate inclusive growth, the public employment agency (ADEM) should continue to increasingly target its interventions at the most vulnerable groups in the labor market. Real wages should remain in line with productivity. Further linking unemployment benefits to job search and training could help reduce inactivity traps. Education reforms should focus on upgrading education outcomes in the context of a multi-lingual society with diverse backgrounds, and on improving the quality of vocational training.

48. Staff Recommends that the next Article IV consultation with Luxembourg be held on the standard 12-month cycle. 
Table 1. Luxembourg: Selected Economic Indicators, 2014-22

\begin{tabular}{|c|c|c|c|c|c|c|c|c|c|}
\hline & 2014 & 2015 & 2016 & 2017 & 2018 & 2019 & 2020 & 2021 & 2022 \\
\hline & & & Est. & \multicolumn{6}{|c|}{ Projections } \\
\hline \multicolumn{10}{|l|}{ Real economy (percent change) } \\
\hline GDP & 4.7 & 3.5 & 4.0 & 3.7 & 3.5 & 3.3 & 3.1 & 3.1 & 3.0 \\
\hline Domestic demand & 3.7 & 2.4 & 2.5 & 4.5 & 3.7 & 3.1 & 2.9 & 2.9 & 2.8 \\
\hline Private consumption & 2.7 & 1.8 & 2.0 & 6.2 & 4.3 & 3.9 & 3.3 & 3.1 & 3.0 \\
\hline Public consumption & -0.1 & 2.3 & 4.0 & 3.4 & 2.8 & 2.2 & 2.2 & 2.7 & 2.6 \\
\hline Gross investment & 8.9 & 3.3 & 1.9 & 2.7 & 3.3 & 2.7 & 3.0 & 2.8 & 2.6 \\
\hline Foreign balance $1 /$ & 1.9 & 1.7 & 2.2 & 1.0 & 1.0 & 1.1 & 1.0 & 1.0 & 1.0 \\
\hline Exports of goods and nonfactor services & 12.1 & 12.8 & 4.2 & 5.0 & 4.1 & 4.2 & 4.3 & 4.3 & 4.1 \\
\hline Imports of goods and nonfactor services & 13.1 & 14.0 & 3.7 & 5.3 & 4.3 & 4.3 & 4.4 & 4.4 & 4.2 \\
\hline \multicolumn{10}{|l|}{ Labor market (thousands, unless noted otherwise) } \\
\hline Resident labor force & 258.0 & 262.6 & 267.0 & 272.1 & 277.3 & 282.5 & 287.9 & 293.4 & 299.0 \\
\hline Unemployed & 18.3 & 17.9 & 17.0 & 16.1 & 15.9 & 15.8 & 15.9 & 16.0 & 15.9 \\
\hline (Percent of labor force) & 7.1 & 6.8 & 6.4 & 5.9 & 5.7 & 5.6 & 5.5 & 5.4 & 5.3 \\
\hline Resident employment & 239.6 & 244.7 & 251.8 & 256.0 & 261.4 & 266.8 & 272.0 & 277.4 & 283.0 \\
\hline (Percent change) & 2.4 & 2.1 & 2.9 & 1.7 & 2.1 & 2.1 & 2.0 & 2.0 & 2.0 \\
\hline Cross border workers (net) & 156.3 & 161.6 & 166.9 & 172.1 & 176.4 & 180.2 & 184.0 & 187.7 & 191.5 \\
\hline Total employment & 395.9 & 406.4 & 418.7 & 428.1 & 437.7 & 447.0 & 456.0 & 465.1 & 474.5 \\
\hline (Percent change) & 2.6 & 2.6 & 3.0 & 2.2 & 2.3 & 2.1 & 2.0 & 2.0 & 2.0 \\
\hline \multicolumn{10}{|l|}{ Prices and costs (percent change) } \\
\hline GDP deflator & 1.5 & 0.4 & 0.9 & 1.3 & 1.5 & 1.7 & 1.9 & 2.0 & 2.0 \\
\hline CPI (harmonized) & 0.7 & 0.1 & 0.1 & 1.4 & 1.3 & 1.7 & 1.9 & 2.0 & 2.0 \\
\hline CPI core (harmonized) & 1.3 & 1.7 & 1.0 & 1.2 & 1.5 & 1.7 & 1.9 & 2.1 & 2.0 \\
\hline CPI (national definition) & 0.6 & 0.5 & 0.4 & 1.3 & 1.4 & 1.7 & 1.9 & 2.0 & 2.0 \\
\hline Wage growth $2 /$ & 2.6 & 0.9 & 0.7 & 2.5 & 2.2 & 2.5 & 2.5 & 2.5 & 2.5 \\
\hline Nominal unit labor costs 2/ & 0.6 & 0.0 & -0.2 & 1.0 & 0.9 & 1.3 & 1.4 & 1.4 & 1.6 \\
\hline \multicolumn{10}{|l|}{ Public finances (percent of GDP) } \\
\hline General government revenues & 43.8 & 43.7 & 43.1 & 41.8 & 41.4 & 41.0 & 41.0 & 40.9 & 40.8 \\
\hline General government expenditures & 42.3 & 42.1 & 41.4 & 41.5 & 41.3 & 41.1 & 41.0 & 40.9 & 40.8 \\
\hline General government balance & 1.5 & 1.6 & 1.7 & 0.3 & 0.1 & 0.0 & 0.0 & 0.0 & 0.0 \\
\hline General government structural balance & 1.3 & 1.5 & 1.5 & 0.2 & 0.0 & -0.2 & 0.0 & 0.0 & 0.0 \\
\hline General government gross debt & 22.7 & 22.1 & 22.6 & 23.2 & 23.5 & 23.2 & 23.0 & 22.8 & 22.9 \\
\hline \multicolumn{10}{|l|}{ Balance of payments (percent of GDP) } \\
\hline Current account & 5.1 & 5.2 & 4.8 & 5.1 & 5.1 & 5.4 & 5.5 & 5.6 & 5.8 \\
\hline Balance on goods & -0.5 & -5.1 & -3.8 & -3.7 & -3.7 & -3.4 & -3.4 & -3.3 & -3.0 \\
\hline Balance on services & 33.7 & 39.7 & 38.0 & 37.1 & 37.2 & 37.3 & 37.3 & 37.4 & 37.4 \\
\hline Net factor income & -29.0 & -31.1 & -31.2 & -30.0 & -30.2 & -30.2 & -30.1 & -30.1 & -30.3 \\
\hline Balance on current transfers & 0.8 & 1.7 & 1.7 & 1.7 & 1.7 & 1.7 & 1.7 & 1.7 & 1.7 \\
\hline \multicolumn{10}{|l|}{ Exchange rates, period averages } \\
\hline U.S. dollars per euro & 1.33 & 1.11 & 1.11 & $\ldots$ & $\ldots$ & $\ldots$ & $\ldots$ & $\ldots$ & $\ldots$ \\
\hline (Percent change) & 0.1 & -16.5 & -0.3 & $\ldots$ & $\ldots$ & $\ldots$ & $\ldots$ & $\ldots$ & $\ldots$ \\
\hline Nominal effective rate $(2010=100)$ & 100.5 & 97.0 & 98.9 & $\ldots$ & $\ldots$ & $\ldots$ & $\ldots$ & $\ldots$ & $\ldots$ \\
\hline (Percent change) & 0.3 & -3.5 & 2.0 & $\ldots$ & $\ldots$ & $\ldots$ & $\ldots$ & $\ldots$ & $\ldots$ \\
\hline Real effective rate $(C P I$ based; $2010=100$ ) & 100.3 & 96.6 & 97.9 & $\cdots$ & $\cdots$ & $\ldots$ & $\cdots$ & $\ldots$ & ... \\
\hline (Percent change) & -0.4 & -3.7 & 1.4 & $\cdots$ & $\cdots$ & $\cdots$ & $\cdots$ & $\cdots$ & ... \\
\hline \multicolumn{10}{|l|}{ Credit growth and interest rates } \\
\hline Credit to nonfinancial private sector (percent change) 3/ & 4.9 & 15.7 & 8.7 & 5.1 & 3.9 & 3.4 & 2.7 & 2.8 & 2.6 \\
\hline Government bond yield, annual average (percent) & 1.3 & 0.4 & 0.2 & $\ldots$ & $\cdots$ & $\ldots$ & $\cdots$ & $\ldots$ & $\ldots$ \\
\hline \multicolumn{10}{|c|}{ Memorandum items: Land area $=2,586$ sq. $\mathrm{km}$; population in $2016=576,000$; GDP per head $=€ 90,400$} \\
\hline GDP (billions of euro) & 49.3 & 51.2 & 53.7 & 56.5 & 59.3 & 62.4 & 65.5 & 68.8 & 72.3 \\
\hline Output gap (percent deviation from potential) & 0.4 & 0.2 & 0.3 & 0.3 & 0.3 & 0.3 & 0.1 & 0.1 & 0.0 \\
\hline Potential output growth (percent) & 3.5 & 3.8 & 3.8 & 3.7 & 3.5 & 3.3 & 3.3 & 3.1 & 3.1 \\
\hline
\end{tabular}




\begin{tabular}{|c|c|c|c|c|c|c|c|c|c|}
\hline \multicolumn{10}{|c|}{$\begin{array}{l}\text { Table 2. Luxembourg: Balance of Payments, 2014-221/ } \\
\text { (Percent of GDP) }\end{array}$} \\
\hline & 2014 & 2015 & 2016 & 2017 & 2018 & 2019 & 2020 & 2021 & 2022 \\
\hline & & & \multicolumn{7}{|c|}{ Projections } \\
\hline Current account & 5.1 & 5.2 & 4.8 & 5.1 & 5.1 & 5.4 & 5.5 & 5.6 & 5.8 \\
\hline Balance on goods and services & 33.3 & 34.6 & 34.2 & 33.4 & 33.5 & 33.8 & 33.9 & 34.1 & 34.4 \\
\hline Trade balance $1 /$ & -0.5 & -5.1 & -3.8 & -3.7 & -3.7 & -3.4 & -3.4 & -3.3 & -3.0 \\
\hline Goods exports & 37.5 & 31.0 & 29.8 & 28.5 & 27.9 & 27.4 & 26.9 & 26.4 & 26.0 \\
\hline Goods imports & 38.0 & 36.1 & 33.5 & 32.2 & 31.6 & 30.8 & 30.3 & 29.7 & 29.0 \\
\hline Balance on services & 33.7 & 39.7 & 38.0 & 37.1 & 37.2 & 37.3 & 37.3 & 37.4 & 37.4 \\
\hline Services exports & 154.0 & 168.3 & 165.7 & 170.2 & 171.6 & 173.6 & 175.9 & 178.2 & 180.4 \\
\hline Services imports & 120.3 & 128.6 & 127.7 & 133.1 & 134.4 & 136.3 & 138.6 & 140.9 & 143.0 \\
\hline Net factor income & -29.0 & -31.1 & -31.2 & -30.0 & -30.2 & -30.2 & -30.1 & -30.1 & -30.3 \\
\hline Compensation of employees, net & -16.5 & -17.0 & -17.2 & -17.2 & -17.1 & -16.9 & -16.8 & -16.7 & -16.6 \\
\hline Compensation of employees, credit & 2.8 & 2.7 & 2.8 & 2.8 & 2.8 & 2.8 & 2.8 & 2.8 & 2.8 \\
\hline Compensation of employees, debit & 19.3 & 19.7 & 20.0 & 20.0 & 19.9 & 19.8 & 19.6 & 19.5 & 19.5 \\
\hline Investment income, net & -12.5 & -14.1 & -14.0 & -12.8 & -13.1 & -13.2 & -13.3 & -13.4 & -13.7 \\
\hline Investment income, credit & 367.0 & 389.1 & 382.9 & 375.5 & 366.4 & 356.1 & 346.1 & 336.0 & 326.4 \\
\hline Investment income, debit & 379.5 & 403.2 & 396.8 & 388.4 & 379.5 & 369.3 & 359.4 & 349.5 & 340.1 \\
\hline Balance on current transfers & 0.8 & 1.7 & 1.7 & 1.7 & 1.7 & 1.7 & 1.7 & 1.7 & 1.7 \\
\hline Capital and financial account & -5.1 & -5.0 & -4.8 & -5.1 & -5.1 & -5.4 & -5.5 & -5.6 & -5.8 \\
\hline Capital account & -2.2 & -1.2 & -1.2 & -1.2 & -1.2 & -1.2 & -1.2 & -1.2 & -1.2 \\
\hline Financial account & 2.9 & 3.9 & 3.6 & 3.9 & 3.9 & 4.2 & 4.3 & 4.5 & 4.6 \\
\hline Direct investment, net & 92.5 & 367.4 & 217.3 & 195.6 & 176.0 & 158.4 & 142.6 & 128.3 & 115.5 \\
\hline Abroad & 292.7 & 1133.9 & 907.3 & 816.5 & 734.8 & 661.2 & 595.0 & 535.4 & 481.8 \\
\hline In reporting economy & 200.2 & 766.4 & 690.0 & 620.9 & 558.8 & 502.8 & 452.4 & 407.1 & 366.3 \\
\hline Portfolio investment, net & -178.1 & -320.0 & -310.9 & -310.9 & -310.9 & -310.9 & -310.9 & -310.9 & -310.9 \\
\hline Portfolio investment, assets & 498.3 & 533.8 & 533.5 & 355.4 & 166.8 & 87.6 & 50.4 & 30.7 & 19.3 \\
\hline Portfolio investment, liabilities & 676.4 & 853.8 & 844.5 & 666.4 & 477.8 & 398.6 & 361.3 & 341.7 & 330.3 \\
\hline Financial derivatives, net & -8.6 & -11.5 & 0.0 & 0.0 & 0.0 & 0.0 & 0.0 & 0.0 & 0.0 \\
\hline Other investment, net & 97.3 & -32.0 & 97.3 & 119.3 & 138.8 & 156.7 & 172.7 & 187.1 & 200.1 \\
\hline Other investment, assets & 213.5 & -56.1 & 275.6 & 275.6 & 275.6 & 275.6 & 275.6 & 275.6 & 275.6 \\
\hline Other investment, liabilities & 116.2 & -24.1 & 178.3 & 156.3 & 136.8 & 118.8 & 102.9 & 88.5 & 75.5 \\
\hline Reserve assets & -0.2 & -0.1 & 0.0 & 0.0 & 0.0 & 0.0 & 0.0 & 0.0 & 0.0 \\
\hline Errors and omissions & 0.0 & -0.2 & 0.0 & 0.0 & 0.0 & 0.0 & 0.0 & 0.0 & 0.0 \\
\hline
\end{tabular}




\begin{tabular}{|c|c|c|c|c|c|c|c|c|c|}
\hline \multicolumn{10}{|c|}{$\begin{array}{l}\text { Table 3. Luxembourg: General Government Operations, 2014-22 } \\
\text { (Percent of GDP) }\end{array}$} \\
\hline & 2014 & 2015 & 2016 & 2017 & 2018 & 2019 & 2020 & 2021 & 2022 \\
\hline & & & Est. & \multicolumn{6}{|c|}{ Projections } \\
\hline Revenue & 43.8 & 43.7 & 43.1 & 41.8 & 41.4 & 41.0 & 41.0 & 40.9 & 40.8 \\
\hline Taxes & 27.1 & 26.7 & 26.3 & 25.5 & 25.1 & 24.8 & 24.8 & 24.7 & 24.7 \\
\hline Social contributions & 12.1 & 12.2 & 12.0 & 12.0 & 12.0 & 11.9 & 11.9 & 11.8 & 11.7 \\
\hline Other revenue & 4.6 & 4.6 & 4.6 & 4.2 & 4.2 & 4.2 & 4.2 & 4.2 & 4.2 \\
\hline Expenditure & 42.3 & 42.1 & 41.4 & 41.5 & 41.3 & 41.1 & 41.0 & 40.9 & 40.8 \\
\hline Expense & 40.8 & 40.4 & 39.8 & 39.9 & 39.7 & 39.5 & 39.3 & 39.2 & 39.2 \\
\hline Compensation of employees & 8.8 & 8.8 & 8.6 & 8.7 & 8.6 & 8.6 & 8.5 & 8.4 & 8.4 \\
\hline Use of goods and services & 3.6 & 3.6 & 3.5 & 3.6 & 3.6 & 3.5 & 3.4 & 3.4 & 3.4 \\
\hline Interest & 0.4 & 0.4 & 0.4 & 0.4 & 0.4 & 0.3 & 0.3 & 0.4 & 0.3 \\
\hline Social benefits & 20.5 & 20.1 & 19.8 & 19.7 & 19.6 & 19.6 & 19.6 & 19.6 & 19.6 \\
\hline Other expense & 7.4 & 7.5 & 7.5 & 7.5 & 7.5 & 7.5 & 7.5 & 7.5 & 7.5 \\
\hline Net acquisition of nonfinancial assets & 1.6 & 1.7 & 1.6 & 1.6 & 1.6 & 1.6 & 1.6 & 1.6 & 1.6 \\
\hline Gross operating balance & 5.2 & 5.4 & 5.5 & 4.1 & 3.8 & 3.7 & 3.8 & 3.8 & 3.7 \\
\hline Net operating balance & 3.0 & 3.3 & 3.3 & 1.9 & 1.7 & 1.6 & 1.6 & 1.6 & 1.6 \\
\hline Net lending / borrowing & 1.5 & 1.6 & 1.7 & 0.3 & 0.1 & 0.0 & 0.0 & 0.0 & 0.0 \\
\hline Net acquisition of financial assets & 3.5 & 2.3 & $\ldots$ & $\ldots$ & $\ldots$ & $\ldots$ & $\ldots$ & $\ldots$ & .. \\
\hline Monetary gold and SDRs & 0.0 & 0.0 & $\ldots$ & $\ldots$ & $\ldots$ & $\ldots$ & $\ldots$ & $\ldots$ & .. \\
\hline Currency and deposits & 1.1 & 0.6 & $\ldots$ & $\ldots$ & $\ldots$ & $\ldots$ & $\ldots$ & $\ldots$ & .. \\
\hline Securities other than shares & 0.2 & 1.4 & $\ldots$ & $\ldots$ & $\ldots$ & $\ldots$ & $\cdots$ & $\cdots$ &.. \\
\hline Loans & 0.7 & -0.1 & $\ldots$ & $\ldots$ & $\ldots$ & $\ldots$ & $\ldots$ & $\ldots$ & .. \\
\hline Shares and other equity & 0.5 & -0.5 & $\ldots$ & $\ldots$ & $\ldots$ & $\ldots$ & $\ldots$ & $\ldots$ & .. \\
\hline guarantee schemes & $\ldots$ & $\ldots$ & $\ldots$ & $\ldots$ & $\ldots$ & $\ldots$ & $\ldots$ & $\ldots$ & .. \\
\hline Financial derivatives & 0.0 & 0.0 & $\ldots$ & $\ldots$ & $\ldots$ & $\ldots$ & $\ldots$ & $\ldots$ & .. \\
\hline Other accounts receivable & 0.9 & 0.3 & $\cdots$ & $\cdots$ & $\cdots$ & $\ldots$ & $\cdots$ & $\cdots$ &.. \\
\hline Net incurrence of liabilities & 2.1 & 0.7 & $\ldots$ & $\ldots$ & $\ldots$ & $\ldots$ & $\ldots$ & $\ldots$ & .. \\
\hline Special Drawing Rights (SDRs) & $\ldots$ & $\ldots$ & $\ldots$ & $\ldots$ & $\ldots$ & $\ldots$ & $\ldots$ & $\ldots$ & .. \\
\hline Currency and deposits & 0.0 & 0.0 & $\ldots$ & $\ldots$ & $\ldots$ & $\ldots$ & $\ldots$ & $\ldots$ & .. \\
\hline Securities other than shares & 0.4 & 0.0 & $\ldots$ & $\ldots$ & $\ldots$ & $\ldots$ & $\ldots$ & $\ldots$ & .. \\
\hline Loans & 0.2 & 0.2 & $\ldots$ & $\ldots$ & $\ldots$ & $\ldots$ & $\ldots$ & $\ldots$ & .. \\
\hline Shares and other equity & 0.0 & 0.0 & $\ldots$ & $\ldots$ & $\ldots$ & $\ldots$ & $\ldots$ & $\ldots$ & .. \\
\hline Insurance technical reserves & 0.0 & 0.0 & $\ldots$ & $\ldots$ & $\ldots$ & $\ldots$ & $\ldots$ & $\ldots$ & .. \\
\hline Financial derivatives & -0.1 & 0.0 & $\ldots$ & $\ldots$ & $\cdots$ & $\ldots$ & $\cdots$ & $\cdots$ & .. \\
\hline Other accounts payable & 1.4 & 0.5 & $\ldots$ & $\cdots$ & $\ldots$ & $\ldots$ & $\ldots$ & $\cdots$ & .. \\
\hline \multicolumn{10}{|l|}{ Memorandum items: } \\
\hline Structural balance & 1.3 & 1.5 & 1.5 & 0.2 & 0.0 & -0.2 & 0.0 & 0.0 & 0.0 \\
\hline Output gap & 0.4 & 0.2 & 0.3 & 0.3 & 0.3 & 0.3 & 0.1 & 0.1 & 0.0 \\
\hline Public gross debt (Maastricht definition) & 22.7 & 22.1 & 22.6 & 23.2 & 23.5 & 23.2 & 23.0 & 22.8 & 22.9 \\
\hline
\end{tabular}


Table 4. Luxembourg: General Government Financial Balance Sheet, 2012-15

(Millions of euros unless noted otherwise)

\begin{tabular}{|c|c|c|c|c|c|c|c|c|c|c|}
\hline & \multirow[t]{2}{*}{2012} & \multicolumn{3}{|c|}{2013} & \multicolumn{3}{|c|}{2014} & \multicolumn{3}{|c|}{2015} \\
\hline & & \multicolumn{3}{|c|}{ Other } & \multicolumn{3}{|c|}{ Other } & \multicolumn{3}{|c|}{ Other } \\
\hline & \multirow{2}{*}{$\begin{array}{l}\text { Closing } \\
\text { balance }\end{array}$} & \multicolumn{2}{|c|}{ Trans- economic } & \multirow{2}{*}{$\begin{array}{l}\text { Closing } \\
\text { balance }\end{array}$} & \multicolumn{2}{|c|}{ Trans- economic } & \multirow{2}{*}{$\begin{array}{l}\text { Closing } \\
\text { balance }\end{array}$} & \multicolumn{2}{|c|}{ Trans- economic } & \multirow{2}{*}{$\begin{array}{l}\text { Closing } \\
\text { balance }\end{array}$} \\
\hline & & actions & flows & & actions & flows & & actions & flows & \\
\hline Net financial worth & 21,862 & 445 & 1,340 & 23,647 & 718 & 736 & 25,101 & 771 & -282 & 25,615 \\
\hline Financial assets & 35,159 & 1,400 & 1,080 & 37,639 & 1,740 & 1,438 & 40,817 & 1,160 & -282 & 41,695 \\
\hline Currency and deposits & 5,817 & 402 & 0 & 6,219 & 557 & 0 & 6,776 & 323 & -297 & 6,802 \\
\hline Debt securities & 6,917 & 677 & -314 & 7,280 & 90 & 577 & 7,947 & 707 & 48 & 8,702 \\
\hline Loans & 1,492 & 149 & 0 & 1,641 & 339 & 0 & 1,980 & -40 & 0 & 1,940 \\
\hline Equity and inv. fund shares & 15,300 & 443 & 1,216 & 16,959 & 227 & 1,043 & 18,229 & -255 & 176 & 18,149 \\
\hline Financial derivatives & 67 & -199 & 179 & 47 & 91 & -182 & -44 & 268 & -208 & 16 \\
\hline Other financial assets & 5,566 & -73 & 0 & 5,493 & 436 & 0 & 5,929 & 156 & 0 & 6,086 \\
\hline Liabilities & 13,297 & 955 & -260 & 13,992 & 1,022 & 702 & 15,717 & 363 & 0 & 16,080 \\
\hline Currency and deposits & 237 & 12 & 0 & 249 & 11 & 0 & 260 & 11 & 0 & 272 \\
\hline Debt securities & 5,456 & 1,050 & -260 & 6,247 & 200 & 702 & 7,149 & 0 & 0 & 7,149 \\
\hline Loans & 4,345 & 245 & 0 & 4,590 & 108 & 0 & 4,698 & 94 & 0 & 4,792 \\
\hline Other liabilities & 3,259 & -352 & 0 & 2,907 & 703 & 0 & 3,610 & 258 & 0 & 3,867 \\
\hline Statistical discrepancy & & 0 & & & 0 & & & 26 & & \\
\hline \multicolumn{11}{|l|}{ Memorandum items: } \\
\hline Net financial worth (percent of GDP) & 49.8 & & & 51.0 & & & 50.9 & & & 50.0 \\
\hline Financial assets (percent of GDP) & 80.1 & & & 81.2 & & & 82.8 & & & 81.4 \\
\hline Liabilities (percent of GDP) & 30.3 & & & 30.2 & & & 31.9 & & & 31.4 \\
\hline GDP & 43,905 & & & 46,353 & & & 49,273 & & & 51,216 \\
\hline
\end{tabular}


Table 5. Luxembourg: International Investment Position, 2012-16 ${ }^{1 /}$

\begin{tabular}{|c|c|c|c|c|c|}
\hline & 2012 & 2013 & 2014 & 2015 & 2016 \\
\hline \multicolumn{6}{|l|}{ Billions of Euros } \\
\hline International investment position & 22.9 & 20.6 & 16.5 & 18.3 & 20.3 \\
\hline Assets & $6,213.8$ & $6,746.9$ & $8,490.8$ & $9,790.2$ & $10,712.6$ \\
\hline Liabilities & $6,190.9$ & $6,726.4$ & $8,474.3$ & $9,771.8$ & $10,692.3$ \\
\hline Direct investment & 393.7 & 383.9 & 379.3 & 512.0 & 628.8 \\
\hline Assets & $2,762.1$ & $3,033.4$ & $4,097.2$ & $4,925.3$ & $5,412.9$ \\
\hline Liabilities & $2,368.4$ & $2,649.6$ & $3,717.8$ & $4,413.3$ & $4,784.1$ \\
\hline Portfolio investment & -622.9 & -640.9 & -650.5 & -774.5 & -941.6 \\
\hline Assets & $2,328.4$ & $2,544.4$ & $3,060.7$ & $3,448.8$ & $3,735.6$ \\
\hline Liabilities & $2,951.3$ & $3,185.3$ & $3,711.3$ & $4,223.3$ & $4,677.1$ \\
\hline Financial derivatives & 4.5 & -0.1 & 14.5 & 7.1 & 7.1 \\
\hline Assets & 167.2 & 165.6 & 127.8 & 187.0 & 187.0 \\
\hline Liabilities & 162.8 & 165.7 & 113.3 & 179.9 & 179.9 \\
\hline Other investment & 246.9 & 277.0 & 272.4 & 273.0 & 325.3 \\
\hline Assets & 955.4 & $1,002.8$ & $1,204.3$ & $1,228.3$ & $1,376.4$ \\
\hline Liabilities & 708.5 & 725.8 & 931.9 & 955.3 & $1,051.1$ \\
\hline Reserve assets & 0.8 & 0.7 & 0.7 & 0.7 & 0.7 \\
\hline \multicolumn{6}{|l|}{ Percent of GDP } \\
\hline International investment position & 52.2 & 44.4 & 33.5 & 35.8 & 37.9 \\
\hline Assets & $14,152.9$ & $14,555.7$ & $17,232.1$ & $19,115.3$ & $19,934.4$ \\
\hline Liabilities & $14,100.7$ & $14,511.3$ & $17,198.6$ & $19,079.5$ & $19,896.6$ \\
\hline Direct investment & 896.8 & 828.1 & 769.9 & 999.7 & $1,170.1$ \\
\hline Assets & $6,291.1$ & $6,544.2$ & $8,315.3$ & $9,616.6$ & $10,072.5$ \\
\hline Liabilities & $5,394.4$ & $5,716.1$ & $7,545.4$ & $8,616.9$ & $8,902.4$ \\
\hline Portfolio investment & $-1,418.8$ & $-1,382.7$ & $-1,320.2$ & $-1,512.2$ & $-1,752.1$ \\
\hline Assets & $5,303.2$ & $5,489.3$ & $6,211.8$ & $6,733.9$ & $6,951.3$ \\
\hline Liabilities & $6,722.0$ & $6,871.9$ & $7,532.1$ & $8,246.1$ & $8,703.4$ \\
\hline Financial derivatives & 10.1 & -0.1 & 29.5 & 13.9 & 13.3 \\
\hline Assets & 380.8 & 357.3 & 259.4 & 365.2 & 348.1 \\
\hline Liabilities & 370.7 & 357.5 & 229.9 & 351.3 & 334.8 \\
\hline Other investment & 562.4 & 597.6 & 552.9 & 533.0 & 605.3 \\
\hline Assets & $2,176.0$ & $2,163.4$ & $2,444.2$ & $2,398.2$ & $2,561.2$ \\
\hline Liabilities & $1,613.6$ & $1,565.8$ & $1,891.3$ & $1,865.3$ & $1,956.0$ \\
\hline Reserve assets & 1.7 & 1.5 & 1.4 & 1.4 & 1.4 \\
\hline
\end{tabular}

Sources: STATEC and IMF Staff estimates.

1/ Balance of Payments Manual 6 (BPM6) presentation. 
Table 6. Luxembourg: Financial Soundness Indicators, 2012-16

(Percent)

\begin{tabular}{|c|c|c|c|c|c|}
\hline & 2012 & 2013 & 2014 & 2015 & $2016 Q 3$ \\
\hline \multicolumn{6}{|l|}{ All Banks } \\
\hline \multicolumn{6}{|l|}{ Capital adequacy } \\
\hline Regulatory capital to risk weighted assets & 19.0 & 21.0 & 20.0 & 22.0 & 23.0 \\
\hline Regulatory tier 1 capital to risk weighted assets & 17.0 & 18.0 & 19.0 & 21.0 & 23.0 \\
\hline Capital to assets & 6.0 & 6.0 & 6.0 & 7.0 & 8.0 \\
\hline \multicolumn{6}{|l|}{ Profitability and efficiency } \\
\hline Return on assets & 0.6 & 0.6 & 0.7 & 0.8 & 0.7 \\
\hline Return on equity & 10.0 & 10.0 & 12.0 & 11.0 & 10.0 \\
\hline Interest margin to gross income & 31.0 & 29.0 & 27.0 & 27.0 & 27.0 \\
\hline \multicolumn{6}{|l|}{ Asset quality and structure } \\
\hline Residential real estate loans to total loans & 4.0 & 4.0 & 4.0 & 4.0 & 4.0 \\
\hline Household debt to GDP & 55.0 & 55.0 & 60.0 & 59.0 & 62.0 \\
\hline Nonperforming loans to total gross loans & 0.2 & 0.2 & $\ldots$ & $\ldots$ & $\ldots$ \\
\hline \multicolumn{6}{|l|}{ Sectoral distribution of loans (in percent of total loans) } \\
\hline Residents & 23.0 & 21.0 & 21.0 & 27.0 & 30.0 \\
\hline Nonresidents & 77.0 & 79.0 & 79.0 & 73.0 & 70.0 \\
\hline \multicolumn{6}{|l|}{ Liquidity } \\
\hline Liquid assets to total assets & 58.0 & 60.0 & 60.0 & 58.0 & $\ldots$ \\
\hline Liquid assets to short-term liabilities & 69.0 & 70.0 & 70.0 & 67.0 & $\ldots$ \\
\hline Customer deposits to total (non interbank) loans & 129.0 & 147.0 & 154.0 & 144.0 & 118.0 \\
\hline \multicolumn{6}{|l|}{ Domestically Oriented Banks } \\
\hline \multicolumn{6}{|l|}{ Capital adequacy } \\
\hline Regulatory capital to risk weighted assets & 24.4 & 26.3 & 23.1 & 22.6 & 23.3 \\
\hline Regulatory tier 1 capital to risk weighted assets & 21.8 & 23.3 & 22.5 & 22.2 & 22.9 \\
\hline Capital to assets & 8.5 & 8.9 & 8.5 & 8.4 & 8.2 \\
\hline \multicolumn{6}{|l|}{ Profitability and efficiency } \\
\hline Return on assets & 0.8 & 1.0 & 1.0 & 1.0 & 1.0 \\
\hline Return on equity & 9.2 & 10.9 & 11.3 & 11.8 & 18.0 \\
\hline Interest margin to gross income & 63.9 & 56.2 & 59.8 & 59.6 & 60.0 \\
\hline \multicolumn{6}{|l|}{ Asset quality and structure } \\
\hline Residential real estate loans to total loans & 21.5 & 24.0 & 27.0 & 28.0 & 27.0 \\
\hline \multicolumn{6}{|l|}{ Household debt to GDP } \\
\hline Nonperforming loans to total gross loans & 0.3 & 0.3 & $\ldots$ & $\ldots$ & 2.2 \\
\hline \multicolumn{6}{|l|}{ Sectoral distribution of loans (in percent of total loans) } \\
\hline Residents & 51.9 & 55.0 & 59.0 & 67.0 & 68.0 \\
\hline Nonresidents & 48.1 & 45.0 & 41.0 & 33.0 & 32.0 \\
\hline \multicolumn{6}{|l|}{ Liquidity } \\
\hline Liquid assets to total assets & 44.4 & 43.2 & 42.9 & 44.0 & $\ldots$ \\
\hline Liquid assets to short-term liabilities & 54.4 & 53.2 & 50.6 & 51.0 & $\ldots$ \\
\hline Customer deposits to total (non interbank) loans & 141.1 & 151.1 & 143.6 & 137.6 & 138.0 \\
\hline
\end{tabular}


Table 7. Luxembourg: Public Sector Debt Sustainability Analysis (DSA)—Baseline Scenario (In percent of GDP unless otherwise indicated)

Debt, Economic and Market Indicators ${ }^{1 /}$

\begin{tabular}{|c|c|c|c|c|c|c|c|c|c|c|c|c|}
\hline & \multicolumn{3}{|c|}{ Actual } & \multicolumn{6}{|c|}{ Projections } & \multirow{2}{*}{\multicolumn{3}{|c|}{$\begin{array}{l}\text { As of January 10, } 2017 \\
\text { Sovereign Spreads }\end{array}$}} \\
\hline & $2006-2014{ }^{21}$ & 2015 & 2016 & 2017 & 2018 & 2019 & 2020 & 2021 & 2022 & & & \\
\hline Nominal gross public debt & 17.1 & 22.1 & 22.9 & 23.2 & 23.4 & 23.6 & 23.8 & 24.1 & 24.3 & Bond Sprea & $d(b p) 3 /$ & 14 \\
\hline Public gross financing needs & 0.9 & 0.3 & 0.5 & 1.5 & 0.9 & 2.1 & 5.3 & 4.3 & 5.5 & $5 Y$ CDS (bp) & & n.a. \\
\hline Real GDP growth (in percent) & 2.7 & 3.5 & 3.7 & 3.4 & 3.3 & 3.2 & 3.1 & 3.0 & 3.0 & Ratings & Foreign & Local \\
\hline Inflation (GDP deflator, in percent) & 3.1 & 0.4 & 0.8 & 1.4 & 1.5 & 1.7 & 1.9 & 1.9 & 2.0 & Moody's & Aaa & Aaa \\
\hline Nominal GDP growth (in percent) & 5.9 & 3.9 & 4.6 & 4.8 & 4.8 & 4.9 & 5.1 & 5.0 & 5.0 & S\&Ps & AAA & AAA \\
\hline Effective interest rate (in percent) ${ }^{4 /}$ & 3.2 & 1.9 & 1.9 & 1.6 & 1.4 & 1.3 & 1.3 & 1.7 & 1.7 & Fitch & AAA & AAA \\
\hline
\end{tabular}

\section{Contribution to Changes in Public Debt}

\begin{tabular}{|c|c|c|c|c|c|c|c|c|c|c|c|}
\hline & \multicolumn{3}{|c|}{ Actual } & \multicolumn{8}{|c|}{ Projections } \\
\hline & 2006-2014 & 2015 & 2016 & 2017 & 2018 & 2019 & 2020 & 2021 & 2022 & cumulative & debt-stabilizing \\
\hline Change in gross public sector debt & 1.7 & -0.7 & 0.8 & 0.2 & 0.2 & 0.3 & 0.2 & 0.3 & 0.3 & 1.4 & primary \\
\hline Identified debt-creating flows & 0.6 & -0.3 & -0.3 & 0.4 & 0.4 & 0.5 & 0.5 & 0.6 & 0.7 & 3.1 & balance $^{9 /}$ \\
\hline Primary deficit & 0.9 & 0.2 & 0.2 & 1.1 & 1.1 & 1.3 & 1.3 & 1.3 & 1.5 & 7.7 & -0.8 \\
\hline Primary (noninterest) revenue and & gra 29.5 & 30.0 & 29.7 & 28.8 & 28.6 & 28.4 & 28.3 & 28.1 & 28.0 & 170.3 & \\
\hline Primary (noninterest) expenditure & 30.5 & 30.2 & 30.0 & 29.9 & 29.8 & 29.7 & 29.6 & 29.5 & 29.5 & 177.9 & \\
\hline Automatic debt dynamics ${ }^{5 /}$ & -0.4 & -0.5 & -0.6 & -0.7 & -0.8 & -0.8 & -0.9 & -0.7 & -0.8 & -4.6 & \\
\hline Interest rate/growth differential ${ }^{6 /}$ & -0.4 & -0.5 & -0.6 & -0.7 & -0.8 & -0.8 & -0.9 & -0.7 & -0.8 & -4.6 & \\
\hline Of which: real interest rate & 0.0 & 0.3 & 0.2 & 0.0 & 0.0 & -0.1 & -0.2 & -0.1 & -0.1 & -0.4 & \\
\hline Of which: real GDP growth & -0.4 & -0.8 & -0.8 & -0.7 & -0.7 & -0.7 & -0.7 & -0.7 & -0.7 & -4.2 & \\
\hline Exchange rate depreciation ${ }^{7 /}$ & 0.0 & 0.0 & 0.0 & $\ldots$ & $\ldots$ & $\ldots$ & $\ldots$ & $\ldots$ & $\ldots$ & $\ldots$ & \\
\hline Other identified debt-creating flows & 0.0 & 0.0 & 0.0 & 0.0 & 0.0 & 0.0 & 0.0 & 0.0 & 0.0 & 0.0 & \\
\hline Please specify (1) (e.g., privatizati & on $\mathrm{r} 0.0$ & 0.0 & 0.0 & 0.0 & 0.0 & 0.0 & 0.0 & 0.0 & 0.0 & 0.0 & \\
\hline Contingent liabilities & 0.0 & 0.0 & 0.0 & 0.0 & 0.0 & 0.0 & 0.0 & 0.0 & 0.0 & 0.0 & \\
\hline Please specify (2) (e.g., other deb & t flo 0.0 & 0.0 & 0.0 & 0.0 & 0.0 & 0.0 & 0.0 & 0.0 & 0.0 & 0.0 & \\
\hline Residual, including asset changes ${ }^{8 /}$ & 1.1 & -0.4 & 1.2 & -0.2 & -0.2 & -0.2 & -0.3 & -0.4 & -0.5 & -1.7 & \\
\hline
\end{tabular}
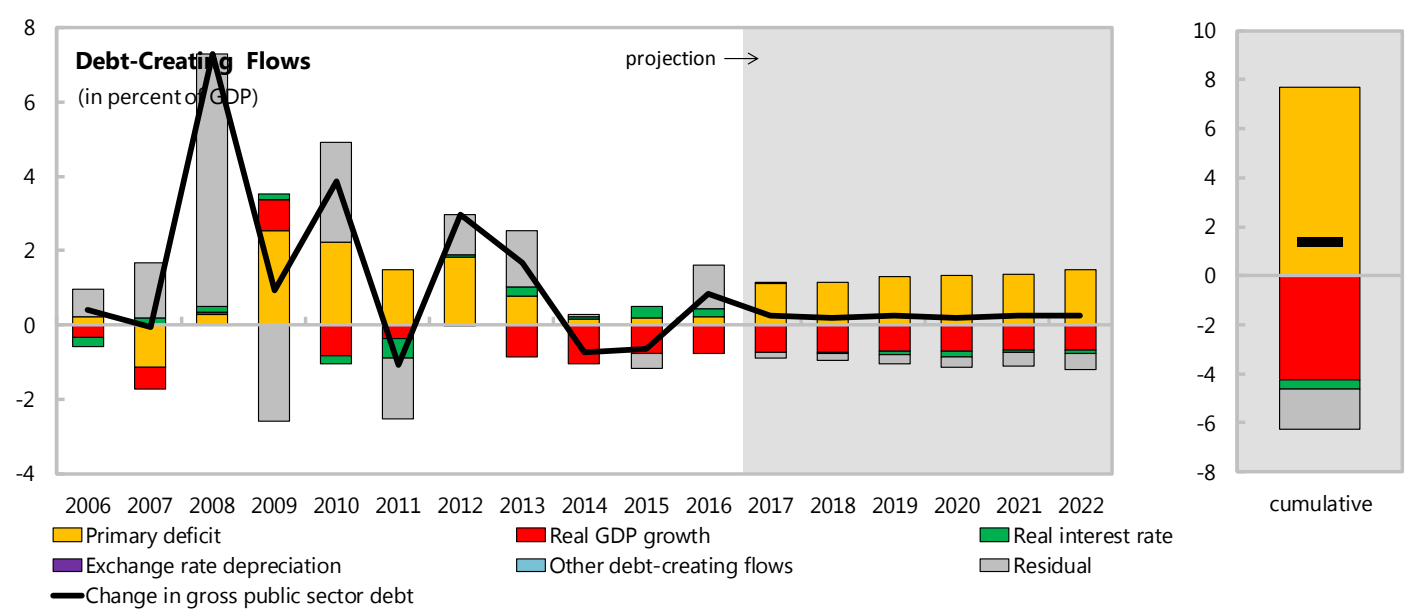

cumulative

\section{$\square$ Exchange rate depreciation}

$\square$ Real GDP growth

$\square$ Real inter

Source: IMF staff.

$1 /$ Public sector is defined as central government.

2/ Based on available data.

3/ Long-term bond spread over German bonds (bp).

4/ Defined as interest payments divided by debt stock (excluding guarantees) at the end of previous year.

5/ Derived as $[r-\pi(1+g)-g+a e(1+r)] /(1+g+\pi+g \pi)$ times previous period debt ratio, with $r=$ effective nominal interest rate; $\pi=$ growth rate of GDP deflator;

$\mathrm{g}=$ real GDP growth rate; $\mathrm{a}=$ share of foreign-currency denominated debt; and $\mathrm{e}=$ nominal exchange rate depreciation (measured by increase in local currency value

of U.S. dollar).

$6 /$ The real interest rate contribution is derived from the numerator in footnote 5 as $r-\pi(1+g)$ and the real growth contribution as $-g$.

$7 /$ The exchange rate contribution is derived from the numerator in footnote 5 as ae $(1+r)$.

8 / Includes asset changes and interest revenues (if any). For projections, includes exchange rate changes during the projection period.

9/ Assumes that key variables (real GDP growth, real interest rate, and other identified debt-creating flows) remain at the level of the last projection year. 
Table 8. Luxembourg: Public DSA—Composition of Public Debt and Alternative Scenarios

\section{Composition of Public Debt}

\section{By Maturity}

(in percent of GDP)

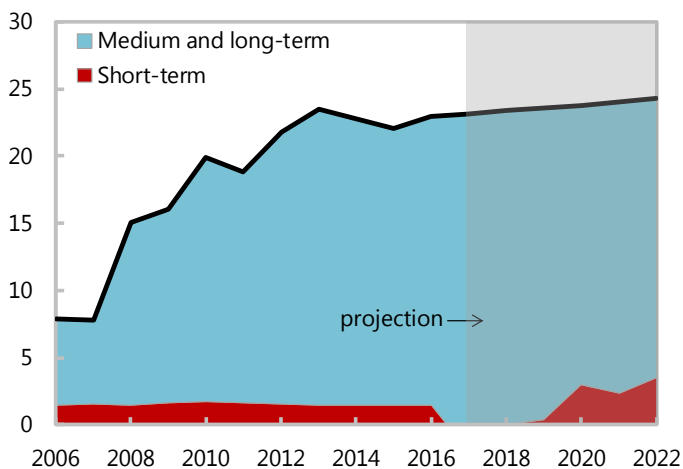

\section{By Currency}

(in percent of GDP)

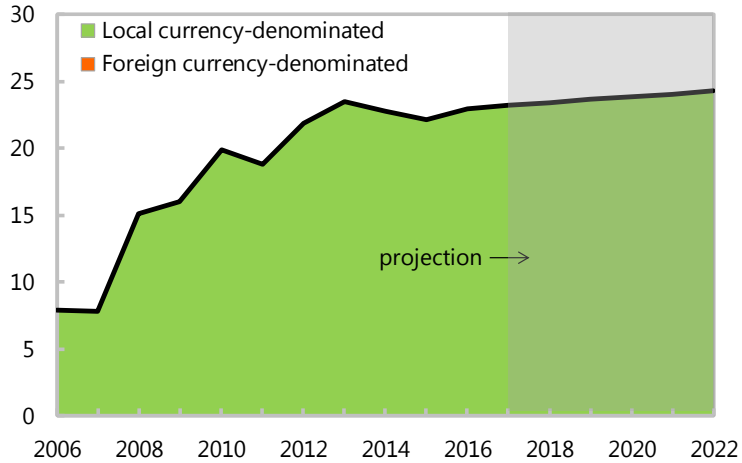

Alternative Scenarios

Contingent Liability Shock

" " Historical

- - Constant Primary Balance

Gross Nominal Public Debt ${ }^{1 /}$

(in percent of GDP)

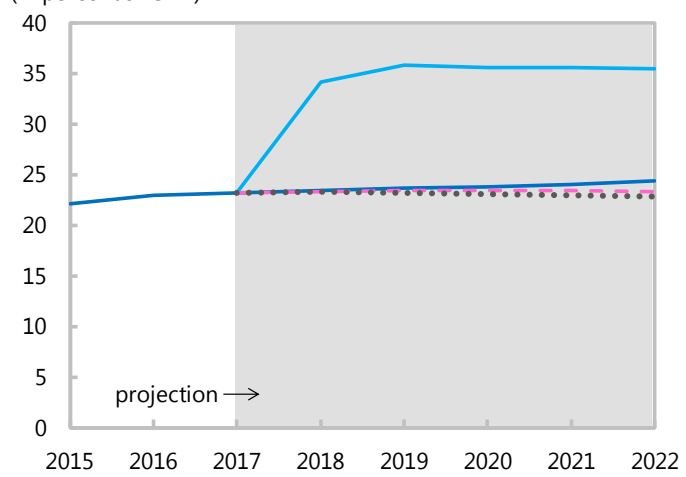

Public Gross Financing Needs

(in percent of GDP)

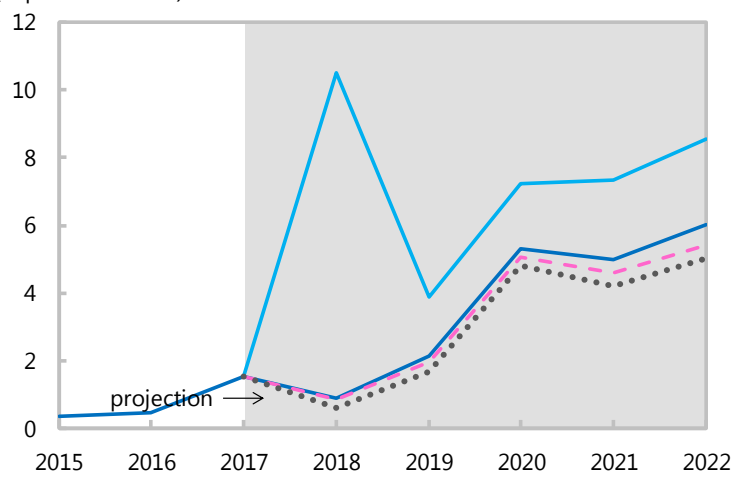

Underlying Assumptions

(in percent)

\begin{tabular}{lcccccc}
\cline { 2 - 7 } Baseline Scenario & 2017 & 2018 & 2019 & 2020 & 2021 & 2022 \\
\cline { 2 - 7 }$\quad$ Real GDP growth & 3.4 & 3.3 & 3.2 & 3.1 & 3.0 & 3.0 \\
Inflation & 1.4 & 1.5 & 1.7 & 1.9 & 1.9 & 2.0 \\
$\quad$ Primary Balance & -1.1 & -1.1 & -1.3 & -1.3 & -1.3 & -1.5 \\
Effective interest rate & 1.6 & 1.4 & 1.3 & 1.3 & 1.8 & 1.7 \\
$\quad$ Constant Primary Balance Scenario & & & & & \\
$\quad$ Real GDP growth & 3.4 & 3.3 & 3.2 & 3.1 & 3.0 & 3.0 \\
$\quad$ Inflation & 1.4 & 1.5 & 1.7 & 1.9 & 1.9 & 2.0 \\
Primary Balance & -1.1 & -1.1 & -1.1 & -1.1 & -1.1 & -1.1 \\
Effective interest rate & 1.6 & 1.4 & 1.3 & 1.3 & 1.8 & 1.7 \\
\hline
\end{tabular}

\begin{tabular}{lcccccc} 
Historical Scenario & 2017 & 2018 & 2019 & 2020 & 2021 & 2022 \\
\cline { 2 - 7 }$\quad$ Real GDP growth & 3.4 & 2.6 & 2.6 & 2.6 & 2.6 & 2.6 \\
$\quad$ Inflation & 1.4 & 1.5 & 1.7 & 1.9 & 1.9 & 2.0 \\
$\quad$ Primary Balance & -1.1 & -0.9 & -0.9 & -0.9 & -0.9 & -0.9 \\
$\quad$ Effective interest rate & 1.6 & 1.4 & 1.3 & 1.3 & 2.0 & 2.0 \\
Contingent Liability Shock & & & & & & \\
$\quad$ Real GDP growth & 3.4 & -0.5 & -0.7 & 3.1 & 3.0 & 3.0 \\
Inflation & 1.4 & 0.5 & 0.7 & 1.9 & 1.9 & 2.0 \\
$\quad$ Primary Balance & -1.1 & -10.7 & -1.3 & -1.3 & -1.3 & -1.5 \\
Effective interest rate & 1.6 & 1.7 & 1.8 & 1.7 & 2.0 & 1.9 \\
\hline
\end{tabular}

1 The financial sector contingent liability shock assumes a one-time non-interest expenditure increase of $10 \%$ of banking sector assets and a growth reduction by one standard deviation for two consecutive years.

Source: IMF staff. 


\begin{tabular}{|c|c|c|c|}
\hline \multicolumn{4}{|c|}{ Table 9. Luxembourg: Risk Assessment Matrix ${ }^{1}$} \\
\hline Source of risks & $\begin{array}{l}\text { Relative likelihood and } \\
\text { transmission channels }\end{array}$ & Impact if realized & Policy response \\
\hline $\begin{array}{l}\text { Business model risk: } \\
\text { Changes in EU and } \\
\text { international taxation } \\
\text { rules and transparency } \\
\text { standards for cross- } \\
\text { border activities }\end{array}$ & \begin{tabular}{l}
\multicolumn{1}{c}{ Medium } \\
A large share of fiscal revenues \\
depends on cross border \\
operations
\end{tabular} & \begin{tabular}{l}
\multicolumn{1}{c}{ High } \\
Tax base erosion and reduction \\
of budget revenues
\end{tabular} & $\begin{array}{l}\text { Diversify fiscal revenue } \\
\text { base, develop } \\
\text { contingency plans, and } \\
\text { continue pension reform }\end{array}$ \\
\hline $\begin{array}{l}\text { Global risk: } \\
\text { Structurally weak } \\
\text { growth in key } \\
\text { advanced and } \\
\text { emerging economies. }\end{array}$ & $\begin{array}{l}\text { High } \\
\text { Luxembourg is particularly } \\
\text { vulnerable to adverse shocks in } \\
\text { the EA given its strong trade } \\
\text { and financial linkages. }\end{array}$ & \begin{tabular}{l}
\multicolumn{1}{c}{ Medium } \\
Adverse impact on export and \\
GDP growth.
\end{tabular} & $\begin{array}{l}\text { Diversify financial services } \\
\text { exports toward non euro } \\
\text { area markets, advance } \\
\text { structural reforms and } \\
\text { infrastructure investments } \\
\text { to boost competitiveness }\end{array}$ \\
\hline $\begin{array}{l}\text { Global risk: } \\
\text { Retreat from cross- } \\
\text { border integration. }\end{array}$ & $\begin{array}{l}\text { High } \\
\text { Protectionism and economic } \\
\text { isolationism would impact trade } \\
\text { and FDI. Luxembourg's exports } \\
\text { of goods account for about } 30 \\
\text { percent of GDP, and imports for } \\
36 \text { percent. Moreover, foreign } \\
\text { direct investment liabilities } \\
\text { account for } 150 \text { times GDP. The } \\
\text { financial sector, which account } \\
\text { for } 1 / 4 \text { of GDP would also be } \\
\text { affected if financial markets } \\
\text { become volatile. }\end{array}$ & $\begin{array}{l}\text { High } \\
\text { Significant impact on domestic } \\
\text { economy through exports of } \\
\text { goods or financial services, and } \\
\text { the possible retreat of } \\
\text { multinational companies that } \\
\text { generate a sizable share of fiscal } \\
\text { revenues. Impact could be } \\
\text { limited if protectionism does not } \\
\text { impact Luxembourg export } \\
\text { sectors and fiscal revenues, and } \\
\text { financial markets benefit from } \\
\text { upside risks to US growth. }\end{array}$ & $\begin{array}{l}\text { Liberalize product } \\
\text { markets to support } \\
\text { diversification of the } \\
\text { economy and ensure } \\
\text { robust contingency plans } \\
\text { stand ready to provide } \\
\text { liquidity support to banks. }\end{array}$ \\
\hline $\begin{array}{l}\text { Global risk: } \\
\text { Heightened risk of } \\
\text { fragmentation/security } \\
\text { dislocation in part of } \\
\text { the Middle East, Africa, } \\
\text { and Europe, leading to } \\
\text { a sharp rise in } \\
\text { refugees. }\end{array}$ & $\begin{array}{l}\text { High } \\
\text { Lack of integration of refugees } \\
\text { into the labor force could raise } \\
\text { unemployment rates and put } \\
\text { pressure on national budgets. }\end{array}$ & $\begin{array}{l}\text { Low } \\
\text { Short-term fiscal costs would be } \\
\text { commensurate with the size of } \\
\text { refugee inflows. Large inflows } \\
\text { could undermine social cohesion. }\end{array}$ & $\begin{array}{l}\text { Integrate refugees into } \\
\text { the labor force as fast as } \\
\text { possible through } \\
\text { language classes and } \\
\text { training. }\end{array}$ \\
\hline
\end{tabular}

\footnotetext{
${ }^{1}$ The Risk Assessment Matrix (RAM) shows events that could materially alter the baseline path (the scenario most likely to materialize in the view of IMF staff). The relative likelihood is the staff's subjective assessment of the risks surrounding the baseline ("low" is meant to indicate a probability below 10 percent, "medium" a probability between 10 and 30 percent, and "high" a probability between 30 and 50 percent). The RAM reflects staff views on the source of risks and overall level of concern as of the time of discussions with the authorities. Non-mutually exclusive risks may interact and materialize jointly. "Short term" and "medium term" are meant to indicate that the risk could materialize within 1 year and 3 years, respectively.
} 
Table 9. Luxembourg: Risk Assessment Matrix (Concluded)

\begin{tabular}{|c|c|c|c|}
\hline Source of risks & $\begin{array}{l}\text { Relative likelihood and } \\
\text { transmission channels }\end{array}$ & Impact if realized & Policy response \\
\hline $\begin{array}{l}\text { Global risk: } \\
\text { Policy uncertainty and } \\
\text { divergence, Two-sided } \\
\text { risks to U.S. growth with } \\
\text { difficult to predict } \\
\text { policies and global } \\
\text { spillovers. In Europe, } \\
\text { uncertainty associated } \\
\text { with negotiating post- } \\
\text { Brexit arrangements and } \\
\text { with upcoming major } \\
\text { elections. Policy } \\
\text { divergence could lead } \\
\text { to rising global } \\
\text { imbalances and } \\
\text { exacerbate exchange } \\
\text { rate and capital flow } \\
\text { volatility. }\end{array}$ & $\begin{array}{l}\text { High } \\
\text { Luxembourg is particularly } \\
\text { exposed to shocks in the EU } \\
\text { which could disrupt financial } \\
\text { sector flows, including } \\
\text { investment funds. } \\
\text { The new Brexit arrangements } \\
\text { could lessen London's appeal as } \\
\text { a financial center, as UK-based } \\
\text { banks and investment funds } \\
\text { could lose their "passporting" } \\
\text { rights to the rest of the EU. } \\
\text { Luxembourg's investment funds } \\
\text { have large exposures to US } \\
\text { capital markets. }\end{array}$ & $\begin{array}{l}\text { High } \\
\text { A negative outcome from elections } \\
\text { would have substantial effects on } \\
\text { financial flows and economic } \\
\text { confidence. An extended period of } \\
\text { heightened uncertainty during the } \\
\text { Brexit negotiations is expected to } \\
\text { weigh on confidence and postpone } \\
\text { consumption and investment, } \\
\text { reducing the growth outlook, } \\
\text { particularly in the UK and the rest of } \\
\text { Europe. The magnitude of these } \\
\text { effects is uncertain and could be } \\
\text { substantially larger than projected } \\
\text { in the baseline, especially if the } \\
\text { process is volatile and/or has } \\
\text { significant political repercussions }\end{array}$ & $\begin{array}{l}\text { Ensure robust } \\
\text { contingency planning } \\
\text { for operational risks } \\
\text { that may arise in the } \\
\text { event of heightened } \\
\text { market volatility, and } \\
\text { stand ready to provide } \\
\text { liquidity support to } \\
\text { banks } \\
\text { Re-double efforts to } \\
\text { secure the benefits of } \\
\text { economic integration } \\
\text { and cooperation across } \\
\text { Europe. }\end{array}$ \\
\hline
\end{tabular}




\section{Appendix I. International Tax Transparency and Anti-Tax Avoidance Initiatives and EC Decisions on Advanced Tax Rulings ${ }^{1}$}

The potential size of Luxembourg's inward foreign investment subject to tax transparency and anti-tax avoidance issues could be very large. EC state aid decisions and EU and G20/OECD tax transparency and anti-tax avoidance initiatives would limit Luxembourg's and other national authorities' discretion to provide favorable tax treatment to multinational companies. If implemented, these initiatives could reduce incentives for multinationals to conduct business through the country, thereby giving rise to downside fiscal risks.

FDI potentially subject to international tax transparency and anti-tax avoidance issues is very large in Luxembourg. Luxembourg is among the top 3 countries in the world for inward and outward FDI. Most of it is accounted for by multinationals' treasury activities, with limited substantial presence in the country. According to the IMF Coordinated Direct Investment Survey, Luxembourg ranked second in the world in 2015, with $\$ 3.2$ trillion inward direct investment in 2015, or 57 times GDP, while the U.S. ranked third. ${ }^{2}$ The top three countries for both inward and outward direct investment in Luxembourg are the United States, the United Kingdom and the Netherlands, and their combined share of direct investment accounts for more than 50 percent of the total.

The EC has decided that the advance tax rulings (ATR) of Fiat in Luxembourg, Starbucks in the Netherlands, and Apple in Ireland as well as the Belgian "excess profit" tax scheme involved improper state aid. ${ }^{3}$ The EC has requested the national tax authorities to recover the improper tax advantages. For Fiat and Starbucks, the repayments could amount to €20-30 million. For Apple, the EC has requested that Ireland must recover the unpaid taxes from Apple for the years 2003 to 2014 of up to $€ 13$ billion, plus interest. Belgium was requested to recover about $€ 700$ million from at least 35 companies. The national authorities disagreed with the EC decisions and have appealed them at the European Court of Justice, which could take a few years to consider the cases.

The EC decisions set an important precedent for reexamining the tax treatment of multinational companies in Luxembourg and across the EU. Currently, the EC is probing the legality of Amazon's, MacDonald's', and GDF-Suez Group's (now Engie) ATRs in Luxembourg and potential repayments can be high. The same approach could be applied to re-examining tax payments of any company that obtained a favorable tax ruling from the national authorities in Luxembourg and other EU countries over the last 10 years.

The EC decisions on ATRs come on top of the OECD/G20 push for tax transparency and antitax avoidance measures. The Action Plan on Base Erosion and Profit Shifting (BEPS) launched by the OECD in 2013 at the G20's behest identified 15 needed actions. In September 2014, the OECD

\footnotetext{
${ }^{1}$ Prepared by Thierry Tressel (EUR).

${ }^{2}$ Equity and debt instruments between affiliated firms are included. However, this amount excludes debt between affiliated financial corporations (defined as deposit taking financial corporations, investment funds, other financial intermediaries except insurance corporations and pension funds).

${ }^{3}$ http://europa.eu/rapid/press-release IP-15-5880 en.htm http://europa.eu/rapid/press-release IP-16-42 en.htm
} 
published a set of reports with policy recommendations on seven of these, and policy recommendations on the remaining measures were published in October 2015 (see Box A1). The proposed measures aim to neutralize so-called hybrid mismatch arrangements that exploit differences in tax treatment between countries. They also address "treaty shopping" and other forms of arbitrage. The framework of BEPS includes monitoring of implementation and of the impact of the different BEPS measures. In addition, the OECD called for automatic sharing of information on the allocation of profits, economic activity, and taxation of multinationals. The G20 summit in November 2015 endorsed recommendations of the OECD project on combating BEPS that address harmful tax practices and pave the way for automatic exchange of information for tax purposes from 2017 (see below). During 2016, the OECD released various documents to implement action 13 on the automatic exchange of information. Changes in U.S. corporate taxation may also be revisited under the new administration.

\section{Box A1. BEPS Actions}

Action 1: addressing the tax challenges of the digital economy and identifying the main difficulties that it poses for the application of existing international tax rules;

Action 2: designing domestic rules to neutralize the effects of hybrid instruments and entities (e.g. double non-taxation, double deduction, long-term deferral);

Action 3: strengthening the rules for the taxation of controlled foreign corporations;

Action 4: preventing base erosion through the use of interest expense (such as the use of related-party and third-party debt to achieve excessive interest deductions or to finance the production of exempt or deferred income);

Action 5: countering harmful tax practices with a focus on improving transparency, including compulsory spontaneous exchange on rulings related to preferential regimes, and on requiring substantial activity for preferential regimes, such as IP regimes;

Action 6: developing treaty provisions and recommendations regarding the design of domestic rules to prevent treaty abuse;

Action 7: preventing the artificial avoidance of permanent establishement status (test of substantial presence);

Actions 8-10: aligning transfer pricing with value creation in relation to intangibles, including hard-to-value ones, to risks and capital, and to other high-risk transactions;

Action 11: measuring and monitoring BEPS;

Action 12: designing mandatory disclosure rules for aggressive tax planning schemes;

Action 13: designing guidance on transfer pricing documentation, including the template for country-bycountry reporting, to enhance transparency while taking into consideration compliance costs;

Action 14: making dispute resolution mechanisms more effective;

Action 15: developing a multilateral insrument to modify bilateral tax treaties.

Various tax transparency and anti-tax avoidance initiatives are under way in the EU. The hitherto confidential national ATRs have been open for bilateral exchange between tax authorities upon request and will be automatically shared from 2017. This decision followed the "LuxLeaks" publications in late 2014, revealing that Luxembourg's ATRs allowed companies to legally reduce their effective tax rates to as low as 1 percent. The European Commission has also put out an 
ambitious agenda to implement anti-BEPS actions, the Anti-Tax Avoidance Package (ATAP) and has relaunched proposals for a Common Consolidated Corporate Tax Base (CCCTB) that are currently under discussion.

- The ATAP contains several Directives and other measures that will have a direct impact on Luxembourg. The Anti-Tax-Avoidance Directive (ATAD), adopted in June 2016, contains five legally-binding anti-abuse measures, which all Member States should apply against common forms of aggressive tax planning, and that are complemented by a proposal published in October 2016 to strengthen the existing rule on hybrid mismatches. Measures are related to rules on interest rate deductibility, exit taxation, and preventing double non-taxation of corporate income, as well as general anti-abuse rules, and rules to prevent profit shifting to a foreign company. These measures should be applied by Member States from January 1, 2019. A revision of the Administrative Cooperation Directive, adopted in December 2015, strengthens cross-border administrative tax cooperation, including on transfer pricing. The ATAP also contains a recommendation on tax treaties, a communication on the external strategy for effective taxation to develop a stronger and more coherent EU approach to working with third countries, and a study on aggressive tax planning.

- In October 2016, the Commission presented a proposal for a CCCTB Directive which applies to multinational groups operating in the EU with global revenues exceeding EUR 750 million a year. The first stage of this process would establish a common corporate tax base, incentives for R\&D, and measures to counter the debt bias in taxation. The second stage would consolidate profits/losses within the EU and apportion taxes on a country-by-country basis. The CCCTB Directive is part of a package that also includes an improved system to resolve double taxation disputes in the EU and a proposal to extend the rules against hybrid mismatches, as provided for in the ATAD, to hybrid mismatches involving non-EU countries. In April 2016, the EC also proposed related public transparency rules for European and non-European multinationals requiring those operating in the EU with global revenues exceeding EUR 750 million a year to publish key information on where they make their profits and where they pay their tax in the EU on a country-by-country basis. In addition, companies would have to publish an aggregate figure for total taxes paid outside the EU. Luxembourg and other EU member states reportedly oppose the EC proposal for a СССТВ Directive on the ground that this would not comply with the subsidiarity and proportionality principles, and would complicate national budgets

\section{Luxembourg has committed to greater transparency and to aligning its tax practices international standards, and has taken various steps:}

- In late 2014, Luxembourg committed to implementing the OECD Standard for Automatic Exchange of Financial Account Information.

- In 2015, the authorities switched to the automatic exchange of information on interest payments to natural persons under the EU Savings Directive. They also agreed to implement an extension of that Directive to cover account balances and other sources of income, including dividends, from 2017. 
- In January 2016, Luxembourg and 30 other OECD countries signed agreements for the automatic exchange of country reports as well as ATRs and advance price agreements (APAs) on transfer pricing, and has joined the EU-wide automatic exchange of ATRs effective January 2017.

- On July 13, 2016, parliament adopted a law on mandatory automatic exchange of tax information, which transposes the EU Council Directive 2015/2376 and extends the scope of mandatory exchange of information on cross-border ATRs and APAs, but excluding natural persons and legal persons with a turnover below $€ 40$ million from the scope of the law. As a consequence, from January 1, 2017, the Luxembourg tax authorities will exchange information on ATRs and APAs with other EU member states. The law retroactively concerns ATRs and APAs issued, amended or renewed as from January 1, 2012, provided they were still valid on January 1, 2014. Prior to the law's publication, the authorities, in anticipation to the European requirements and based on Action 5 of the OECD BEPS action plan, started to gather the necessary information on past ATRs and APAs and expected to finalize their communication by end-2016.

- Finally, on December 27, 2016, the Ministry of Finance published a circular on the fiscal treatment of intra-group transfers (transfer pricing) aimed at implementing BEPS recommendations. ${ }^{4}$

\section{However, issues on various important aspects of the tax transparency and anti-tax avoidance agenda remain:}

- According to a report by "European Network on Debt and Management" published in December 2016, APAs between European governments and multinationals have increased by more than 160 percent between 2013 and 2015. The same report stated that Luxembourg APAs account for more than one third of all APAs. In response to questioning at the Parliament, the Minister of Finance clarified that ATRs and APAs are agreements that can ensure the predictability of taxes and may not per se be problematic, and noted that the total number of ATRs, including APAs, reached 599 in 2015 and declined to 459 in 2016.

- In April 2016, the "Panama Papers"5 drew attention to Luxembourg and other countries. According to the ICIJ's analysis of the papers, four Luxembourg banks were among the ten banks that had requested the most offshore companies for clients, and Luxembourg ranked fourth in the list of countries with the most active intermediaries and seventh where intermediaries operate. These leaks have raised questions about the role of Luxembourg intermediaries in the creation of opaque structures using foreign legal entities. Following this publication, the CSSF initiated a targeted supervisory review of a number of "high risk" banks, followed by additional supervisory scrutiny of a group of higher risk banks. The conclusions of this review will be published at the end of 2017:Q2.

\footnotetext{
${ }^{4}$ http://www.impotsdirects.public.lu/archive/newsletter/2016/nl 27122016/index.html

${ }^{5}$ The so-called Panama Papers refers to the leak of some 11.5 million documents created over more than 30 years by a Panamanian law firm, Mossack Fonseca, and covering the financial and attorney-client information for more than 210,000 offshore entities that may have been used to hide assets, avoid taxes, or evade financial sanctions.
} 


\section{Appendix II. External Sector Assessment ${ }^{1}$}

Luxembourg's external position is broadly in line with its medium-term fundamentals and desirable policies. This assessment is based on empirical analyses, a review of developments in the balance of payments and net foreign asset position, as well as consideration of Luxembourg's status as a global financial center.

The current account surplus declined slightly to 4.8 percent of GDP in 2016. It is driven mainly by a strong surplus in services only partly offset by a deficit in net factor income. The slight downward trend in the current account in recent years has been driven by an increase in net factor income outflows, particularly net equity portfolio income, and slightly less so by compensation of employees. The net international investment position has strengthened to about $€ 20.3$ billion (37.9 percent of GDP), with gross assets and liabilities both increasing by roughly $91 / 2$ percent fueled by ample

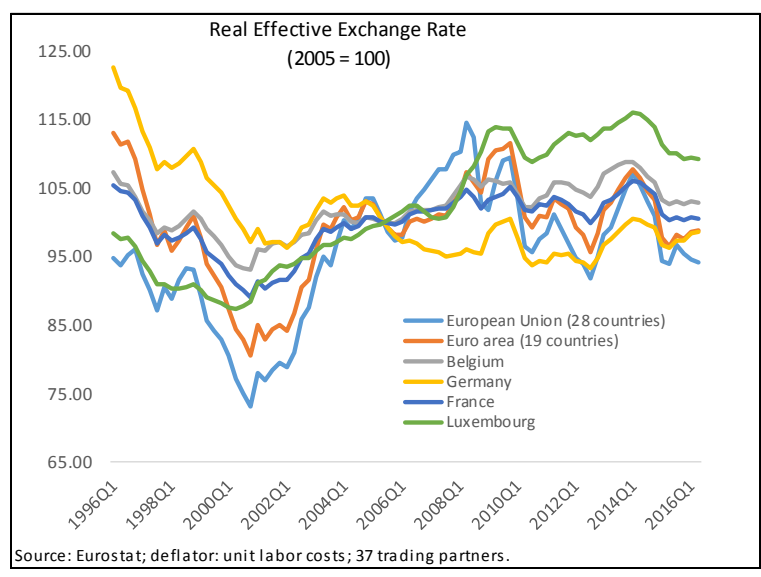
international liquidity. At end-2016, gross external assets and liabilities reached $€ 10.7$ trillion (about 200 times the size of GDP), highlighting Luxembourg's role as a financial center. During the financial crisis, Luxembourg's real effective exchange rate (REER) appreciated somewhat more than its trading partners, mostly driven by an increase in unit labor costs between 2007-09, but in 2016 the REER was only 6 percent above its level at end-2005.

\section{The EBA-lite methodology supplemented with staff judgement indicate that the external} position is broadly in line with fundamentals and desirable policy settings. Given Luxembourg's status as a financial center with large gross external assets and liabilities, and very volatile net foreign assets the External Sustainability Approach is deemed less appropriate. Both the Real Effective Exchange Rate Index Model and the Current Account Approach suggest a slight overvaluation of the real effective exchange and a negative current account gap. Both models, however, can only partially capture Luxembourg's specific circumstances as a financial center, including a large investment fund industry, and as a small economy with a large share of nonresident workers. Exports and imports of financial and ancillary services are less sensitive to relative price changes, and non-resident workers affect net factor income and population-based variables in the models. Additionally, service exports as a percentage of GDP, driven by the banking and investment fund sector, have been steadily increasing since the financial crisis, while goods exports have remained broadly constant as a share of GDP. These facts suggest that no compelling case can be made for a deterioration of competitiveness.

\footnotetext{
${ }^{1}$ Prepared by Anne Oeking (FIN).
} 
- The Real Effective Exchange Rate Index Model (IREER) suggests a moderate overvaluation of 13.2 percent of GDP. The approach takes into account the large number of non-residents working in Luxembourg when estimating productivity (by considering both resident and non-resident workers for output per worker). Besides this adjustment, the measure of trade openness used for Luxembourg excludes exports and imports of financial services (which are likely insensitive to relative price effects).

External Balance Assessment (Lite) Real Exchange Rate Gap External sustainability approach $\quad-1.6 \%$ Current account approach $\quad 4.1 \%$ REER approach $\quad 13.2 \%$

Current account Actual current account $\quad 4.8 \%$ Current account norm $\quad 7.3 \%$ Current account gap $\quad-2.5 \%$ Elasticity of current account $\quad-0.60$

- The Current Account Approach (CA) suggests a CA norm of 7.3 percent of GDP, taking into account Luxembourg's status as a financial center. With an elasticity of the current account balance to movements in the real effective exchange rate of -0.6 , this translates into a slight exchange rate overvaluation of 4.1 percent of GDP.

- The External Sustainability Approach (ES) indicates that a current account surplus of 3.4 percent of GDP would stabilize Luxembourg's net IIP position, which is slightly lower than the actual current account surplus, implying a slightly undervalued exchange rate. 


\section{Appendix III. Financial Sector Oversight in Luxembourg ${ }^{1}$}

The financial sector oversight of Luxembourg has been strengthened in recent years:

- Investment funds. The authorities have adopted the requirements set out in relevant EU legislation (notably the UCITS and AIFM Directives), which are in line with the standards and principles developed by the International Organization of Securities Commissions (IOSCO). Following the recommendations of the 2011 FSAP, the CSSF has also significantly increased its resources devoted to fund management oversight.

- Bank supervision. The authorities have transposed into national law the EU Capital Requirements Directive (CRD IV). Following the introduction of the Single Supervisory Mechanism (SSM) in 2014, 61 of the 144 banks in Luxembourg are now supervised by the ECB, either as Significant Institutions (SIs) in their own right or as subsidiaries or branches of foreign SIs, representing 75 per cent of Luxembourg bank assets. The ECB has also replaced Luxembourg's Finance Minister as the body responsible for bank licensing.

- Bank resolution. The establishment of the Single Resolution Mechanism (SRM) and transposition of relevant EU directives has improved Luxembourg's bank resolution framework. In December 2015, Luxembourg transposed into domestic law the Bank Recovery and Resolution Directive (BRRD) and the Deposit Guarantee Schemes (DGS) Directive. The CSSF was designated as the resolution authority, and requirements for resolution planning by the authorities were adopted. Institutions are required to prepare recovery plans and the CSSF has acquired new intervention powers. The private sector Deposit Guarantee Association has been replaced by a public sector deposit guarantee scheme, the Fonds de Garantie des Dépôts Luxembourg (FGDL), and all Luxembourg banks and branches of non-EU banks must be members. A new governing body in the CSSF (the Conseil de Protection des Déposants et des Investisseurs-CPDI) will administer the deposit guarantee scheme and perform stress tests on FGDL.

- Macroprudential framework. A Comité du Risque Systémique (CRS) was established in April 2015. The CRS brings together the Treasury (Chair), the central bank (Secretariat), and the two supervisors (the CSSF and CAA), tasked with the macroprudential oversight of Luxembourg's financial system.

\footnotetext{
${ }^{1}$ Prepared by Thierry Tressel (EUR).
} 


\section{Appendix IV. 2017 FSAP Recommendations}

\begin{tabular}{|c|c|c|}
\hline Recommendations & Agency & Time \\
\hline \multicolumn{3}{|l|}{ General / cross-cutting } \\
\hline 1. Continue resource allocation toward risk-based supervision at $\mathrm{BCL}, \mathrm{CSSF}$ and $\mathrm{CAA}$ & $\mathrm{BCL}, \mathrm{CSSF}, \mathrm{CAA}$ & NT \\
\hline $\begin{array}{l}\text { Increase engagement with supervision and resolution authorities in countries where } \\
\text { Luxembourg's LSIs and investment funds conduct significant activities }\end{array}$ & CSSF & NT \\
\hline $\begin{array}{l}\text { Enshrine in legislation the operational independence of the CSSF and CAA, and introduce } \\
(C A A, C A A) \text { or update }(B C L) \text { board member codes of conduct }\end{array}$ & $\begin{array}{l}\text { MoF, BCL, } \\
\text { CAA, CSSF }\end{array}$ & NT \\
\hline \multicolumn{3}{|l|}{ Risk Analysis } \\
\hline $\begin{array}{l}\text { 4. Examine merits of a regulatory LCR requirement in FX at the group level and step up } \\
\text { monitoring of related FX liquidity risk }\end{array}$ & EC, ECB & MT \\
\hline $\begin{array}{l}\text { Provide industry guidance on liquidity stress test modalities and liquidity management } \\
\text { tools for investment funds, and develop internal liquidity stress testing capacity }\end{array}$ & CSSF & NT \\
\hline \multicolumn{3}{|l|}{ 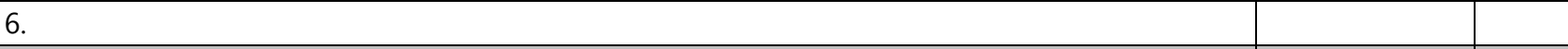 } \\
\hline \multicolumn{3}{|l|}{ Macroprudential Policy } \\
\hline 7. Strengthen the institutional framework in order to increase the willingness to act & MoF, CRS & MT \\
\hline Expand the macroprudential policy toolkit to include borrower based lending limits & MoF, CRS & I \\
\hline $\begin{array}{l}\text { 9. Continue to strengthen risk-based monitoring of the residential real estate market and } \\
\text { bank-investment fund interlinkages, and close remaining related data gaps }\end{array}$ & $\mathrm{CRS}, \mathrm{BCL}, \mathrm{CSSF}$ & I \\
\hline \multicolumn{3}{|l|}{ Banking Regulation and Supervision } \\
\hline $\begin{array}{l}\text { 10. Increase the intensity of supervision over intra-group exposures, with banks required to } \\
\text { demonstrate continued eligibility in their use of large exposure limit waivers }\end{array}$ & CSSF & NT \\
\hline Continue monitoring ability of banks to absorb a real estate market price decline & CSSF, ECB & C \\
\hline Increase frequency of on-site inspections of subsidiaries of SIs & CSSF, ECB & $\mathrm{C}$ \\
\hline 13. Harmonize data reporting standards for loan-to-value and debt-to-income ratios & CSSF, ECB & I \\
\hline \multicolumn{3}{|l|}{ Investment Fund Regulation and Supervision } \\
\hline $\begin{array}{l}\text { 14. Strengthen guidance on substance in the context of delegated activities and actively } \\
\text { engage with regulators in jurisdictions where such activities are prominent }\end{array}$ & CSSF & NT \\
\hline Issue guidance on the holdings of directorships of funds and their managers & CSSF & NT \\
\hline 16. Assess whether safeguards to ensure depositary independence are adequate & CSSF & NT \\
\hline \multicolumn{3}{|l|}{ Insurance Regulation and Supervision } \\
\hline 17. Implement revised early warning system under Solvency II regime & CAA & NT \\
\hline \multicolumn{3}{|l|}{ Financial Market Infrastructure Oversight } \\
\hline 18. Reduce CBL's exposure to commercial banks vis-à-vis CSDs and central banks & CSSF, BCL & NT \\
\hline 19. Require establishment of third data center and conduct a full failover test & $\mathrm{CSSF}, \mathrm{BCL}$ & NT \\
\hline \multicolumn{3}{|l|}{ AML/CFT } \\
\hline 20. Ensure the $2016 / 2017$ national risk assessment focus adequately on TCSP risks & MoF & I \\
\hline \multicolumn{3}{|l|}{ Contingency Planning and Financial Safety Nets } \\
\hline $\begin{array}{l}\text { 21. Develop policies on intragroup exposures and the transfer of custodian functions in } \\
\text { recovery and resolution }\end{array}$ & CSSF, SRB, ECB & I \\
\hline 22. $\quad$ Agree on the roles and responsibilities in dealing with a system-wide crisis & MoF & NT \\
\hline Finalize the operational modalities of emergency liquidity assistance provision & $\mathrm{BCL}$ & MT \\
\hline
\end{tabular}

Agencies: $\mathrm{BCL}=$ Banque centrale du Luxembourg; $\mathrm{CRS}=$ Comité du Risque Systémique; $\mathrm{CSSF}=$ Commission de Surveillance du Secteur Financier; $E C B=$ European Central Bank; MoF = Ministry of Finance; MoJ = Ministry of Justice, $S R B=$ Single Resolution Board. Time Frame: $C=$ continuous; I (immediate) = within one year; NT (near term) $=1-3$ years; MT (medium term) $=3-5$ years. 


\section{Appendix V. Implementation of the 2016 Article IV Recommendations}

\begin{tabular}{|c|c|}
\hline Recommendation & Authorities' Response \\
\hline \multicolumn{2}{|c|}{ Fiscal } \\
\hline $\begin{array}{l}\text { Broaden the tax base and adjust to the changing } \\
\text { international taxation environment. Develop } \\
\text { contingency measures, including revisiting the low } \\
\text { real estate taxes, in case negative revenue risks } \\
\text { materialize. }\end{array}$ & $\begin{array}{l}\text { The authorities are implementing OECD/BEPS } \\
\text { recommendations on exchange of information, } \\
\text { including ATRs, and on transfer pricing, and intend } \\
\text { to transpose the EU Anti-Tax Avoidance Directive. } \\
\text { The IP box is being phased out since } 2016 \text {. }\end{array}$ \\
\hline $\begin{array}{l}\text { In light of revenue risks, run a small fiscal surplus } \\
\text { and keep public debt low. }\end{array}$ & $\begin{array}{l}\text { The tax reform has used a good part of the } \\
\text { available fiscal space, and is expected to result in a } \\
\text { balanced budget over the medium-term while } \\
\text { stabilizing the public debt ratio at about its current } \\
\text { level. }\end{array}$ \\
\hline $\begin{array}{l}\text { The } 2016 \text { pension review should propose } \\
\text { additional parametric reforms of the pension } \\
\text { system, such as of the minimum contributions } \\
\text { period and conditions for early retirement. }\end{array}$ & $\begin{array}{l}\text { A pension group comprising social partners and } \\
\text { the government aims at providing } \\
\text { recommendations for reform of the pension } \\
\text { system before the } 2018 \text { elections. }\end{array}$ \\
\hline \multicolumn{2}{|c|}{ Financial } \\
\hline $\begin{array}{l}\text { Continue strong oversight of investment funds and } \\
\text { their management companies, taking into account } \\
\text { linkages with banks, and ensure that data } \\
\text { monitoring allow identifying funds' sensitivity to } \\
\text { interest rates and credit market movements. }\end{array}$ & $\begin{array}{l}\text { The monitoring and data reporting of funds has } \\
\text { continued to be strengthened by the CSSF, } \\
\text { including on leverage, liquidity, concentration and } \\
\text { securities lending. Studies of funds-bank linkages } \\
\text { are undertaken by the BCL and the CSSF. }\end{array}$ \\
\hline $\begin{array}{l}\text { Advocate for better oversight at the European level } \\
\text { of nonbank holding companies that include banks } \\
\text { and improve risk monitoring. }\end{array}$ & $\begin{array}{l}\text { Regulatory framework for oversight of financial } \\
\text { holding companies is being reviewed by the EU, } \\
\text { and at the SSM level ownership of banks is } \\
\text { monitored at the authorization stage. }\end{array}$ \\
\hline $\begin{array}{l}\text { Continue to closely monitor risks in the real estate } \\
\text { market, explore the effectiveness of recent macro- } \\
\text { prudential measures in containing risks and } \\
\text { whether further measures such as limits to loan-to- } \\
\text { value ratios are appropriate. }\end{array}$ & $\begin{array}{l}\text { The CSSF undertakes stress tests of bank } \\
\text { exposures to real estate, risks are being monitored } \\
\text { by the CRS, and additional measures to build } \\
\text { buffers in the banking system were taken in } \\
\text { August } 2016 \text {. }\end{array}$ \\
\hline \multicolumn{2}{|c|}{ Structural } \\
\hline $\begin{array}{l}\text { Better align workers' skills with the economy's } \\
\text { demands and reduce inactivity traps while } \\
\text { ensuring that real wages remain in line with } \\
\text { productivity. }\end{array}$ & $\begin{array}{l}\text { ADEM has targeted vulnerable groups and market } \\
\text { needs in collaboration with employers, and has } \\
\text { begun to re-evaluate workers with disability to } \\
\text { facilitate their reinsertion in the labor market. } \\
\text { Wage indexation was resumed in January } 2017 .\end{array}$ \\
\hline
\end{tabular}




\section{INTERNATIONAL MONETARY FUND}

\section{LUXEMBOURG}

STAFF REPORT FOR THE 2017 ARTICLE IV

April 14, 2017 CONSULTATION-INFORMATIONAL ANNEX

Prepared By European Department

\section{CONTENTS}

FUND RELATIONS $\underline{2}$ 


\section{FUND RELATIONS}

(As of March 31, 2017)

Membership Status: Joined December 27, 1945; Article VIII.

General Resources Account:

Quota

Fund holding of currency

Reserve Tranche Position

Lending to the Fund

New Arrangements to Borrow

SDR Department:

Net cumulative allocation

Holdings
SDR million

$1,321.80$

$1,171.71$

150.11

83.87
SDR million

246.62

244.78
Percent of quota

100.00

88.64

11.36

Outstanding Purchases and Loans: None

Latest Financial Arrangements: None

Projected Payments to Fund (SDR Million); based on existing use of resources and present holdings of SDRs):

\begin{tabular}{l|llccc}
\multicolumn{7}{c}{} & \multicolumn{5}{c}{ Forthcoming } \\
\multicolumn{1}{l}{ Principal } & 2017 & 2018 & 2019 & 2020 & 2021 \\
Charges/Interest & 0.00 & 0.00 & 0.00 & 0.00 & 0.00 \\
& 0.01 & $\underline{0.02}$ & $\underline{0.02}$ & $\underline{0.02}$ & $\underline{0.02}$
\end{tabular}

Implementation of HIPC Initiative: Not applicable

Safeguards Assessments: Not applicable

Exchange Rate Assessment: Luxembourg's currency is the euro, which floats freely and independently against other currencies. Luxembourg has accepted the obligations of Article VIII, Sections 2, 3, and 4, and maintains an exchange system free of restrictions on payments and transfers for current international transactions, other than restrictions notified to the Fund under Decision No. 144 (52/51). 
Last Article IV Consultation: The last Article IV consultation was concluded on May 06, 2016. The associated Executive Board assessment is available at http://www.imf.org/external/np/sec/pr/2016/pr16216.htm and the staff report (IMF Country Report No. 16/1118) at http://www.imf.org/external/pubs/cat/longres.aspx?sk=43894.0 . Luxembourg is on the standard 12 month consultation cycle.

Financial Sector Assessment Program (FSAP) Participation and ROSC: The Financial System Stability Assessment (FSSA) for the last mandatory FSA was discussed by the Board on May 13, 2011. The FSSA and accompanying Reports on the Observation of Standards and Codes (ROSCs) are available at http://www.imf.org/external/pubs/cat/longres.aspx?sk=24995.0.

Anti-Money Laundering/Combating the Financing of Terrorism (AML/CFT): In February 2014, the Financial Action Task Force (FATF) recognized that Luxembourg had made significant progress in addressing deficiencies identified in the February 2010 mutual evaluation report and decided to remove the country from the regular follow-up process. The FATF report is available at http://www.fatf-gafi.org/countries/j-m/luxembourg/documents/fur-luxembourg-2014.html. 


\section{STATISTICAL ISSUES}

\section{A. Assessment of Data Adequacy for Surveillance}

General: Data provision is adequate for surveillance, although macroeconomic data are sometimes released with a significant lag. The Central Service for Statistics and Economic Studies (Statec) regularly publishes a full range of economic and financial data and provides an advance release calendar for main statistical releases at http://www.statistiques.public.lu/fr/agenda/calendrierdiffusion/index.html.

Online access to Statec's databases is available to all users simultaneously at the time of release through the Statistics Portal of Luxembourg. Key publicly accessible websites for macroeconomic data and analysis are:

$\begin{array}{ll}\begin{array}{l}\text { Statistics Portal of Luxembourg } \\ \text { Statec }\end{array} & \underline{\text { http://www.statistiques.public.lu/fr/ }} \\ \begin{array}{l}\text { Central Bank of Luxembourg } \\ \text { Ministry of Finance }\end{array} & \underline{\text { http://www.statec.public.lu/fr/index.html }} \\ \text { http://www.mf.public.lu/ }\end{array}$

National Accounts: Luxembourg avails itself of the flexibility under the Special Data Dissemination Standard (SDDS) for the timeliness of its national accounts, generally disseminating national accounts data not later than four months after the reference period (the SDDS timeliness requirement for the national accounts is three months). Frequent and substantial data revisions and publication delays bear on the ability to forecast macroeconomic performance.

\section{B. Data Standards and Quality}

Luxembourg has been a subscriber to the SDDS since May 12, 2006. Luxembourg uses SDDS flexibility options also on the timeliness of the analytical accounts of the central bank.

No data ROSC is available. 
Table of Common Indicators Required for Surveillance

\begin{tabular}{|c|c|c|c|c|c|}
\hline (As of April 11, 2017) & $\begin{array}{l}\text { Date of Latest } \\
\text { Observation }\end{array}$ & $\begin{array}{l}\text { Date } \\
\text { Received }\end{array}$ & $\begin{array}{l}\text { Frequency of } \\
\text { Data }^{7}\end{array}$ & $\begin{array}{l}\text { Frequency of } \\
\text { Reporting }^{7}\end{array}$ & $\begin{array}{l}\text { Frequency of } \\
\text { Publication }^{7}\end{array}$ \\
\hline Exchange Rates & 04/07/17 & $04 / 07 / 17$ & D & $\mathrm{D}$ & $\mathrm{D}$ \\
\hline $\begin{array}{l}\text { International Reserve Assets and } \\
\text { Reserve Liabilities of the Monetary } \\
\text { Authorities }^{1}\end{array}$ & $02 / 28 / 16$ & 03/30/17 & M & M & M \\
\hline Reserve/Base Money & $02 / 28 / 17$ & 03/30/17 & M & M & M \\
\hline Broad Money & $02 / 28 / 17$ & 03/30/17 & M & M & M \\
\hline Central Bank Balance Sheet & $02 / 28 / 16$ & 03/30/17 & M & M & M \\
\hline $\begin{array}{l}\text { Consolidated Balance Sheet of the } \\
\text { Banking System }\end{array}$ & $02 / 28 / 17$ & 03/30/17 & M & M & M \\
\hline Interest Rates ${ }^{2}$ & 04/07/17 & 04/07/17 & $\mathrm{D}$ & $\mathrm{D}$ & $\mathrm{D}$ \\
\hline Consumer Price Index & 03/01/17 & $04 / 05 / 17$ & M & M & M \\
\hline $\begin{array}{l}\text { Revenue, Expenditure, Balance and } \\
\text { Composition of Financing }{ }^{3} \text {-General } \\
\text { Government }{ }^{4}\end{array}$ & 2016 & 04/10/17 & A & A & A \\
\hline $\begin{array}{l}\text { Revenue, Expenditure, Balance and } \\
\text { Composition of Financing }{ }^{3} \text { - Central } \\
\text { Government }\end{array}$ & 2015:Q4 & $02 / 29 / 16$ & Q & Q & Q \\
\hline $\begin{array}{l}\text { Stocks of Central Government and } \\
\text { Central Government-Guaranteed Debt }{ }^{5}\end{array}$ & 2016 & 04/10/17 & Q & $\mathrm{Q}$ & $\mathrm{Q}$ \\
\hline External Current Account Balance & 2016 & $03 / 23 / 16$ & Q & $\mathrm{Q}$ & $\mathrm{Q}$ \\
\hline Exports and Imports of Goods & $01 / 31 / 17$ & 03/28/17 & M & M & M \\
\hline GDP/GNP & 2016:Q4 & $03 / 31 / 17$ & $\mathrm{Q}$ & $\mathrm{Q}$ & $\mathrm{Q}$ \\
\hline Gross External Debt & 2016:Q4 & $03 / 31 / 17$ & $\mathrm{Q}$ & $\mathrm{Q}$ & $\mathrm{Q}$ \\
\hline International Investment Position ${ }^{6}$ & 2016:Q4 & $03 / 23 / 15$ & Q & Q & Q \\
\hline \multicolumn{6}{|c|}{$\begin{array}{l}{ }^{1} \text { Including reserve assets that are pledged or otherwise encumbered. } \\
\text { 2 Both market-based and officially-determined, including discount rates, money market rates, and rates on treasury bills, } \\
\text { notes, and bonds. } \\
{ }^{3} \text { Foreign, domestic bank, and domestic nonbank financing. } \\
{ }^{4} \text { The general government consists of the central government (budgetary funds, extra budgetary funds, and social security } \\
\text { funds) and the state and local governments. } \\
\text { 5Including currency and maturity composition. } \\
{ }^{6} \text { Includes external gross financial asset and liability positions vis-à-vis nonresidents. } \\
{ }^{7} \text { Daily (D); weekly (W); monthly (M); quarterly (Q); annually (A); irregular (I); and not available (NA). }\end{array}$} \\
\hline
\end{tabular}




\title{
INTERNATIONAL MONETARY FUND
}

May 3, 2017

\section{LUXEMBOURG}

\section{STAFF REPORT FOR THE 2017 ARTICLE IV}

CONSULTATION—SUPPLEMENTARY INFORMATION

\author{
Prepared By $\quad$ European Department
}

This supplement provides information that has become available since the cut-off date of the staff report's projections. The thrust of the staff appraisal is unchanged.

\section{Following publication of the preliminary 2016 national accounts, the authorities} updated their growth and fiscal projections in the Stability and Growth Program released at end-April. The revised national accounts show somewhat higher growth than projected for 2016 and previous years. In view of the volatile international environment, the authorities expect significant fluctuations of the projected GDP growth around the long-term trend, while staff envisages a gradual convergence to it. The authorities project a somewhat higher unemployment rate over the medium term. Staff's revised projections imply only small changes relative to the staff report. Luxembourg's medium-term objective (MTO) has remained a structural fiscal deficit of 0.5 percent of GDP, and the authorities reaffirmed their commitment to keep the gross public debt below 30 percent of GDP over the medium term. The government's fiscal deficit and public debt projections-underpinned by a strong fiscal surplus of 1.6 percent of GDP in 2016-are consistent with those of the staff report, although the government projections show an increase in the fiscal balance from 2018, partly due to an assumed diminishing cost of the tax reform over time. 
Luxembourg: Updated Projections and Fiscal Estimates, 2016-21

$\begin{array}{llllll}2016 & 2017 & 2018 & 2019 & 2020 & 2021\end{array}$

Projections

Real GDP growth (percent change)

Staff report

Revised Staff Projections

Authorities' April Update

Foreign balance (percentage point contribution to growth)

Staff report

Revised Staff Projections

Authorities' April Update

Unemployment rate (percent, national definition)

Staff report

Revised Staff Projections

Authorities' April Update

General government balance (percent of GDP)

Staff report

Revised Staff Projections

Authorities' April Update

General government gross debt (percent of GDP)

Staff report

Revised Staff Projections

Authorities' April Update

$\begin{array}{llllll}4.0 & 3.7 & 3.5 & 3.3 & 3.1 & 3.1 \\ 4.2 & 3.8 & 3.5 & 3.3 & 3.1 & 3.1 \\ 4.2 & 4.4 & 5.2 & 4.4 & 2.8 & 1.9\end{array}$

$\begin{array}{llllll}2.2 & 1.0 & 1.0 & 1.1 & 1.0 & 1.0\end{array}$

$\begin{array}{llllll}3.3 & 1.8 & 1.1 & 1.2 & 1.1 & 1.2\end{array}$

$\begin{array}{llllll}3.5 & 0.4 & 2.3 & 2.1 & 1.9 & 1.3\end{array}$

$\begin{array}{llllll}6.4 & 5.9 & 5.7 & 5.6 & 5.5 & 5.4\end{array}$

$\begin{array}{llllll}6.4 & 5.9 & 5.6 & 5.4 & 5.3 & 5.3\end{array}$

$\begin{array}{llllll}6.4 & 6.0 & 5.7 & 5.8 & 6.3 & 6.9\end{array}$

$\begin{array}{llllll}1.7 & 0.3 & 0.1 & 0.0 & 0.0 & 0.0\end{array}$

$\begin{array}{llllll}1.6 & 0.2 & 0.0 & 0.0 & 0.0 & 0.0\end{array}$

$\begin{array}{llllll}1.6 & 0.2 & 0.3 & 0.5 & 0.9 & 1.2\end{array}$

$\begin{array}{llllll}22.6 & 23.2 & 23.5 & 23.2 & 23.0 & 22.8\end{array}$

$\begin{array}{llllll}20.0 & 20.8 & 21.5 & 21.5 & 21.3 & 21.3\end{array}$

$\begin{array}{llllll}20.0 & 22.2 & 22.4 & 22.6 & 22.8 & 22.6\end{array}$

Sources: Luxembourg authorities and IMF staff estimates. 


\section{Statement by Mr. De Lannoy, Executive Director for Luxembourg and Ms. Hubic, Senior Advisor to the Executive Director May 5, 2017}

The authorities thank Mr. De Vrijer and Mr. Breuer, and their respective teams, for the excellent cooperation during the Article IV Consultation and the FSAP exercise in Luxembourg. The analysis presented in their respective reports provides a broadly balanced view of the macroeconomic, fiscal and financial sector developments in the country and the challenges these are facing. The authorities will consider the staff recommendations in the policy decision making.

Macroeconomic outlook

The Luxembourg economy remains strong with buoyant employment and growth prospects. A stable political and social environment, a track record of fiscal prudence and a modern legal and regulatory framework are important factors that support growth, as is the skilled and multilingual workforce. A continuous AAA credit rating with stable outlook confirms the market's confidence in the country.

Over the last three years, the average real GDP growth was 4.6 percent. In 2016, the economy grew by 4.2 percent, mainly driven by robust domestic demand and strong net exports. In the latest update of the Stability and Growth Program, the government projects the economy to grow by 4.4 percent in 2017 and on average by 3.6 percent over the medium term.

Strong and dynamic job creation led to an increase in employment of 3 percent in 2016. Employment creation is projected to even accelerate to 3.2 percent on average over the medium term. Unemployment is declining thanks to favorable growth dynamics and the government's active labor market policies that help tackle youth unemployment, as well as the long-term unemployed low-skilled workers. The employment agency's (ADEM) personalized programs tailored to the needs of unemployed and labor demand, together with reclassifying people with medical conditions, have also helped reduce the unemployment rate, which stood at 6 percent at the beginning of 2017, down from around 6.8 percent in 2015, and is projected to further decrease to about 5.4 percent in 2019.

In line with euro area trends and oil prices, average inflation remains relatively low. However, over the medium term, inflation is projected to an average 1.8 percent. The current account has eased to 5 percent of GDP in 2016. It is expected to remain at this level in the medium term, reflecting a surplus in services partly offset by a negative balance in goods. The authorities agree with staff that the external position is broadly in line with fundamentals. 
Despite strong growth prospects, the authorities recognize that some, mostly external, downside risks exist, such as the retreat from cross-border integration and the policy uncertainty at the European and global level. They will therefore continue to maintain sound policies and diversify the economy further, to increase its resilience to shocks. In this context, the authorities were wondering whether the IMF has assessed similar types of global risks for the financial centers/countries comparable to Luxembourg.

\section{Public finances}

The fiscal position remains sound, with a 1.6 percent of GDP budget surplus in 2016 and a gross public debt level close to 20 percent of GDP. The country has managed to maintain its low level of public debt, well below European reference values and its own 30 percent of GDP ceiling, as well as budgetary safety margins with respect to the rules of the EU Stability and Growth Pact, demonstrating the government's commitment to sound fiscal policies.

The government implemented a significant tax reform on January 1, 2017, targeting both companies and households, with the latter being the largest beneficiaries. The reform aims at supporting the competitiveness of companies and at reinforcing households' purchasing power. The most significant measures were a rebalancing of the personal income tax brackets and the gradual reduction of the headline corporate income tax rate. Other objectives of the reform are to simplify the tax system and to make it fairer. In light of the favorable macroeconomic and fiscal developments, helped by the positive impact of a sizeable consolidation package implemented since 2015, the tax reform is making use of the fiscal space vis-à-vis European fiscal rules while still maintaining sufficient buffers as recommended by staff.

Despite the budgetary impact of the tax reform, the fiscal position is projected to remain close to balance and in slight surplus over the medium-term. The authorities continue to target a high public investment level, at around 4 percent of GDP, in light of the strong population and employment growth projections. The gross public debt stood at 20 percent of GDP in 2016, entirely denominated in euro, and is projected to remain around 23 percent of GDP in the coming years. It is worth noting that significant assets to fund future pension liabilities (32.9 percent of GDP at the end of 2016) have been set aside in a specialized and dedicated fund. And, taking all government assets into account, the public sector remains a net creditor.

Although the fiscal indicators are currently positive, the country is facing some structural challenges that may impact its public finances. Potential growth has somewhat declined and the high degree of openness of the economy and its specialization in financial services make public revenues vulnerable to high volatility. Also, several tax initiatives that are underway 
- such as the OECD/G20 BEPS project or EU rule changes and investigations - may create uncertainty, although Luxembourg could also benefit from a global level playing field given its other competitive advantages. The ageing population may also pose a challenge for public finances over the long-term. The government concurs with staff's view that a close monitoring of the sustainability of the pensions system is required. At the end of 2016, as provided under the 2013 pension reform, the competent authority has presented the financial situation of the pension system based on an actuarial study. In addition, a pension working group was created, comprised of social partners and government representatives, with the goal to provide, if appropriate, recommendations to reform the pension system.

The Luxembourg government has committed to greater transparency and to the alignment of its tax practices with international standards. In that vein, it has taken important steps over the last three years, such as: (i) a commitment to implement the OECD Standard for Automatic Exchange of Information; (ii) an approval of agreements for the automatic exchange of country-by-country reports as well as advance tax rulings and advance price agreements on transfer pricing; and (iii) a publication of a circular on the tax treatment of intra-group financing aimed at implementing BEPS recommendations.

\section{Financial sector}

The authorities appreciate the work done under the 2017 FSAP exercise, and intend to follow up on most recommendations which will help further strengthen Luxembourg's financial model. Some preliminary reactions are presented in the next paragraphs.

The FSAP findings indicate that Luxembourg's forward-looking financial sector, which is interconnected domestically and internationally, remains resilient and sound. The ongoing regulatory changes and uncertainties at European and international levels may present challenges and are closely monitored by the authorities who stand ready to take the necessary measures aimed at preserving the resilience and stability of the financial sector.

The banking sector has maintained high levels of profitability, capital, liquidity and asset quality, and NPLs are very low - both on absolute levels and compared to peers. The sector continues to be profitable and remains an important liquidity provider. The banking union is good for the euro area and especially beneficial for Luxembourg, as the more integrated prudential oversight under the SSM eliminates potential 'blind spots' for the national supervisors, and strengthens the resilience of the banking system. In this regard, the authorities believe that it is essential to complete the banking union, notably by putting in place a common European backstop for the 
single resolution fund as well as the third pillar of the banking union. The authorities also underscore the importance of retaining the supervisory powers of host countries as long as the banking union is not completed in order to preserve the host country's financial stability, including the possibility of imposing liquidity and loss absorption capacity requirements at the level of bank subsidiaries.

The growing investment fund industry remains an important component of the financial system in Luxembourg. Over the last few years, the industry has benefited from new inflows and favorable financial markets which increased the amount of assets under management. It continues to invest in a diversified class of assets and caters to a diverse pool of investors without any major concentration risks. This diversification - together with prudent regulatory and sound supervisory regimes - has been an important factor in the resilience of the overall financial sector during past crises and continues to help buffer against the impact of financial market volatility.

The authorities are supportive of staff's recommendations on the financial sector oversight, including for non-bank holding companies and investment funds and their linkages to banks. The Commission de Surveillance du Secteur Financier (CSSF) has already produced a study on linkages between investment funds and banks, indicating that banks could withstand a sizable redemption shock from investment funds under certain assumptions. Furthermore, the Systemic Risk Committee (SRC) - the national macro-prudential authority - had discussions on this linkage based on a study prepared by the Banque centrale du Luxembourg (BCL), and will continue to analyze and closely monitor this interlinkage considering the CSSF study and the IMF analysis.

Staff's assessment of the financial system's ability to withstand severe shocks suggests resilience of the sector, with the principal risk identified as interruptions to real and financial cross-border flows. The authorities take note of the outcome of the stress testing exercise. It is worth noting that the key risk identified pertains mainly to the structure of global financial operations, and probably applies to any financial sector comparable to the one in Luxembourg.

The government supports the recommendation of a code of conduct for regulators' boards, but disagrees with the recommendation regarding regulators' board composition and governance arrangements. Luxembourg's governance model is commensurate to the strategic importance of the financial center and comparable to that of other supervisory authorities. The government supports staff's recommendation to introduce a formal framework to govern the relationship between the government and banks with a state shareholding. It will look at different models which exist in other euro area member states. 
The authorities welcome staff's thorough assessment of Clearstream, which offers a safe and efficient system of clearing, settlements and custody of securities transactions. Given the importance of this institution, the authorities have asked the ECB to consider designating it as a Significant Institution under the Single Supervisory Mechanism (SSM), alongside Belgium's Euroclear Bank. This will ensure consistent implementation of supervisory requirements and be in line with FSAP 2017 recommendations.

\section{Other issues}

Housing market. Both structural and cyclical factors continue to contribute to the divergence between supply and demand in the housing market. On the demand side, several factors play a role, including high demand from residents and cross-border workers, a relatively high population, immigration growth and low mortgage interest rates. On the supply side, administrative constraints and low recurring taxes on real estate property seem to be the restraining factors. However, staff's analysis shows that the real estate valuations remain broadly in line with economic fundamentals. The authorities recognize the need to continue monitoring this risk - through the SRC - and stand ready to take actions, if needed. In this context, the SRC continues monitoring the domestic residential real estate exposure of domestically-oriented banks, which is important for financial stability, and will recommend additional macro-prudential measures as necessary.

Diversification of the economy. The government continues to pay careful attention to developing a climate conducive to business and investment which should help pursuing efforts to diversify the economy. It remains committed to keep investment levels high. The government has chosen specific sectors of growth such as logistics, ICT and bio- and eco-technologies to support the diversification. It continues looking for possible opportunities by using some of the existing frameworks/infrastructure and encourages innovation. For example, it recently developed a legal framework for space mining which will support the existing ecosystem in this sector. Also, the diversification of the forward-looking financial sector across the business activities, investment destinations and the customer bases is expected to further enhance the diversification of the financial sector itself. Recent efforts by the government to promote fintech and climate finance underline such ambitions.

Educational system. Staff rightly points out that Luxembourg's trilingual education system can be both an asset and a challenge for the highly diverse student population. Difficulties with language learning have led to difficulties in other disciplines, which is reflected in PISA scores. The government has taken this challenge seriously and has introduced measures to diversify and improve education curricula. Staff's view that 'more than half of new jobs created go to cross border commuters, mainly due to skills mismatches, reflecting deficiencies in education and training' is not fully 
accurate. More than half of the unemployed in Luxembourg are long-term unemployed with lower education, who have not previously worked in the financial sector. Many newly created jobs stem from the financial sector and need a workforce with a tertiary education. To tackle this issue, the government objectives are two-fold: (i) introduce proactive targeted measures for the long-term unemployed, and employ them in the newly created real sector activities (e.g. logistics); and (ii) improve/adapt the national education system to better prepare students for the needs of the economy. 